Review Article

\title{
A Review on Superplastic Formation Behavior of Al Alloys
}

\author{
Xiao-guo Wang, ${ }^{1,2}$ Qiu-shu Li $\mathbb{D}^{1},{ }^{1}$ Rui-rui Wu, ${ }^{1}$ Xiao-yuan Zhang, ${ }^{2}$ and Liyun $\mathrm{Ma}^{3}$ \\ ${ }^{1}$ School of Materials Science and Engineering, Taiyuan University of Science and Technology, Taiyuan 030024, China \\ ${ }^{2}$ Department of Mechanical and Electrical Engineering, College of Information, Shanxi Agricultural University, \\ Taigu 030800, China \\ ${ }^{3}$ Department of Mining Engineering, Luliang University, Lishi 033000, China
}

Correspondence should be addressed to Qiu-shu Li; liqiushu@tyust.edu.cn

Received 27 March 2018; Revised 27 June 2018; Accepted 16 July 2018; Published 27 September 2018

Academic Editor: Guru P. Dinda

Copyright (C) 2018 Xiao-guo Wang et al. This is an open access article distributed under the Creative Commons Attribution License, which permits unrestricted use, distribution, and reproduction in any medium, provided the original work is properly cited.

Superplastic formation technology is considered to be an effective and promising method to conquer formation difficulties of $\mathrm{Al}$ alloys, especially thin-walled or complex structure. In this paper, fundamentals of superplastic deformation of $\mathrm{Al}$ alloys are summarized and the superplastic deformation behaviors of main kinds of $\mathrm{Al}$ alloys are summarized and compared, including $\mathrm{Al}$ $\mathrm{Mg}$ alloys, Al-Li alloys, and Al-Zn-Mg alloys as well as aluminum matrix composites. Then, the superplastic deformation mechanism for different $\mathrm{Al}$ alloys is thoroughly discussed. Last but not the least, the factors affecting the superplastic deformation process are fully analyzed.

\section{Introduction}

1.1. Superplasticity of Materials. Generally speaking, superplasticity [1-6] is a characteristic of some materials with equiaxed and fine grains, when they are deformed in tension at relatively high temperature $\left((0.5-0.7) T_{\mathrm{m}}\right)$ and low strain rate $[7,8]$, which has been discovered in various materials. Remarkable elongation is a notable symbol of superplasticity, for example, Sn-Bi eutectic alloys [9] under superplastic tensile tests exhibiting outstanding elongation, as much as $1950 \%$. The superplastic elongations of main $\mathrm{Al}$ alloys can vary from $200 \%$ to $2000 \%$, and the elongation of some superplastic materials can be up to $8000 \%$. The superplastic characteristics of materials tremendously improve their formability with reduced deformation resistance and viscous/semiviscous flow during plastic deformation, particularly for complicated structure components.

It is well acknowledged that strain hardening occurs during plastic deformation, of which the constitutive equation [10] is affected by strain-hardening exponent $n$, as shown in Equation (1). The constitutive equation of superplastic deformation at relatively low temperature abides to viscoplastic Equation (2) proposed by Rossard, which indicates that the process combines strain hardening with strain rate hardening. The constitutive equation of superplastic deformation at relatively high temperature acts up to flow stress Equation (3) proposed by Backofen et al., implying that the process is mainly manipulated by strain rate sensitivity exponent $m$ :

$$
\begin{aligned}
& \sigma=K \varepsilon^{n}, \\
& \sigma=K \varepsilon^{n} \dot{\varepsilon}^{m}, \\
& \sigma=K \dot{\varepsilon}^{m},
\end{aligned}
$$

where $\sigma$ is the true stress, $\varepsilon$ is the true strain, $\dot{\varepsilon}$ is the strain rate, $n$ is the strain-hardening exponent, $m$ is the strain rate sensitivity, and $k$ is a parameter for material.

1.2. Superplastic Formability of Al Alloys. Because of their low density and high specific strength combined with exceptional corrosion resistance, Al [11-14] are the most widely utilized alloys in aerospace, automobiles industry, mechanical manufacturing, marine business, and chemical industry. Superplastic forming technology (SFT), which can dramatically decrease flow/residual stress and improve formation quality, has been commonly used to manufacture 
complex shapes in sheet or tube. The $\mathrm{Al}$ alloys used are capable of achieving equivalent thickness strains in excess of $300 \%$ at low strain rates. Companies like Superform and Alcoa have successfully applied SFT to produce Al alloy automobile parts (decklid, fenders, door inners, and brake disk) with 50\% weight saving [15]. In 1991, $8090 \mathrm{Al}$ alloys were used to produce military aircraft doors by SFT with $23 \%$ weight reduction and $68 \%$ cost reduction.

To enhance the superplastic formability of $\mathrm{Al}$ alloys, it is necessary to make the alloys to go through several advanced forming technologies, such as flake powder metallurgy [16] and cryo-deformation [17-20] as well as severe plastic deformation (SPD) [21], including friction stir processing (FSP) [22-28], equal-channel angular pressing (ECAP) [29-35], high-pressure torsion (HTP) [36], accumulative roll bonding (ARB) [37], multiaxial alternative forging (MAF) [38], and repetitive corrugation and straightening (RCS) $[39,40]$. After SPD process, ultrafine grain, high superplasticity, and low flow stress are available for $\mathrm{Al}$ alloys. Yet, due to high cost, additionally required technologies may hold back the direct and full commercial application of SPD technology. Meanwhile, more and more energy and resources are pouring into developing new and convenient hot/cold mechanical processing for superplasticity of various $\mathrm{Al}$ alloys. Therefore, thermal-mechanical processing (TMP) [41-43], which is mainly based on the principles of static recrystallisation [44-47] and dynamic recrystallisation $[48,49]$, is also an important way to develop superplasticity of $\mathrm{Al}$ alloys.

\section{Fundamentals of Superplastic Deformation of Al Alloys}

2.1. Stacking Fault Energy. It is well known that $\mathrm{Al}$ and $\mathrm{Al}$ alloys are with high stacking fault energy (SFE) which is a significant intrinsic material parameter that would change mechanisms and grain refinement during superplastic deformation. In $\mathrm{Al}$ and $\mathrm{Al}$ alloys, recovery is not totally suppressed during superplastic deformation. Additionally, lowering the SFE would promote deformation twinning over dislocation slip and increase dislocation slip-twinning transition temperature $[50,51]$.

2.2. Strain-Hardening Ability. It is clear that strain hardening is a typical phenomenon in plastic deformation. In the primary stage of superplastic deformation, flow stress rapidly rises with flow strain due to appearance of massive defects (vacancies/dislocations/twinning). As the process goes on, strain softening, due to recovery/recrystallisation/cross slip, starts to offset or partially offset the increase of flow stress until there is a dynamic balance between the hardening and softening processes, namely, steady stage of superplastic deformation. The strain-hardening ability is strongly dependant on temperature and strain rate of superplastic deformation, as shown in Figure 1. The true stress increases with increase in strain rate and decrease in temperature, which is explained in Section 4.2.
2.3. Superplastic Deformation Behavior. After rolling or SPD, $\mathrm{Al}$ alloys consist of banded microstructure with subgrain boundaries (SGBs) and low-angle boundaries (LABs). Following homogenization annealing, $\mathrm{Al}$ alloys are recrystallised and the microstructure combined with equiaxed recrystallised grains with weakened banded grains is formed before superplastic tensile tests. The early stage of superplastic deformation of $\mathrm{Al}$ alloys is usually accompanied with static/ dynamic grain growth and anisotropic grain elongation. It should be noticed that grains are more elongated in the tensile direction than in the transverse direction $[53,54]$. Yet, the static/dynamic grain growth is closely related to the distribution of intermetallic precipitates, which is fully discussed in Section 4.2. With the increase in strain, the previous microstructure is replaced by a more equiaxed and uniform grain structure and the banded grains are vanished.

2.4. Crystallographic Texture. Crystallographic texture is a preferred orientation structure of grains in ploycrystalline materials.

Being subjected to the formation process (casting, rolling, recrystallisation, and heat treatment), $\mathrm{Al}$ and $\mathrm{Al}$ alloys, typical FCC ploycrystalline materials, would produce corresponding texture. The main crystallographic texture components in FCC metals are listed in Table 1.

Prior to superplastic deformation, the microtexture of rolled/SPD Al alloys is of a strong brass texture [17, 55], which is a dominant plane strain hot deformation texture for $\mathrm{Al}$ alloys. After homogenization annealing for proper period, $\mathrm{Al}$ alloys exhibit cube, near cube, rotated cube, or decreased brass component. As the strain of superplastic deformation increases, a randomization of the microtexture happens along with the increase in misoriented boundaries; therefore, the alloys exhibit a very weak texture component as cube, near cube, rotated cube, or decreased brass component. Figure 2 shows ODFs representative sections of Al-Zn-Mg$0.25 \mathrm{Sc}-0.10 \mathrm{Zr}$ during superplastic deformation. In summary, the overall texture intensity of Al alloys is substantially reduced following superplastic deformation and no new orientation is developed.

2.5. Strain Rate Sensitivity $(m)$ and Deformation Activation Energy (Q). Usually, superplastic deformation can be described by an equation for power-law creep in the following form:

$$
\dot{\varepsilon}=A \frac{D_{0} G b}{R T}\left(\frac{b}{d}\right)^{p}\left(\frac{\sigma}{G}\right)^{1 / m} \exp \left(-\frac{Q}{R T}\right),
$$

where $\dot{\varepsilon}$ the is strain rate, $Q$ is the activation energy of an appropriate diffusion process, $A$ and $p$ are the empirical material constants, $G$ is the shear modulus, $b$ is the Burgers vector, $R$ is the gas constant, $T$ is the absolute temperature, $D_{0}$ is the frequency factor, and $m$ is the strain rate sensitivity exponent $(1 / m$ is the stress exponent $n, n=1 / m)$.

Strain rate sensitivity $(m)$ is a critical parameter for superplastic deformation, as its value characterizes the ability of an alloy to resist necking spread during 


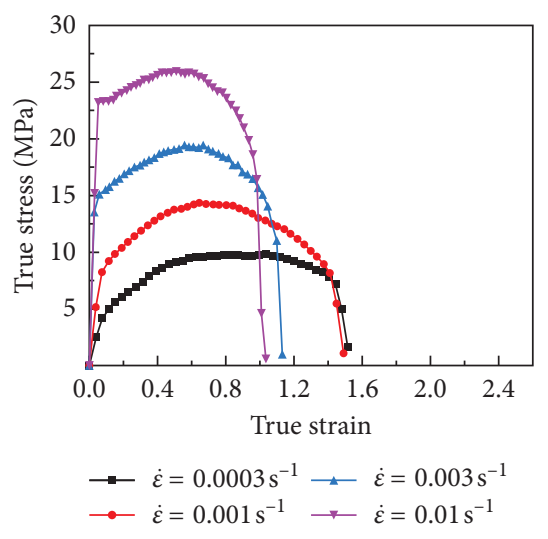

(a)

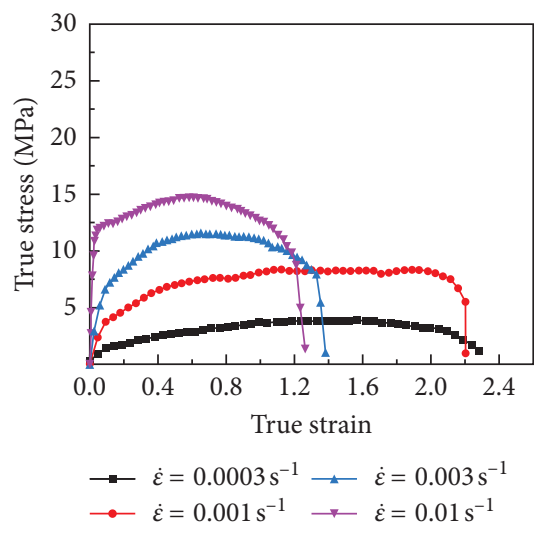

(d)

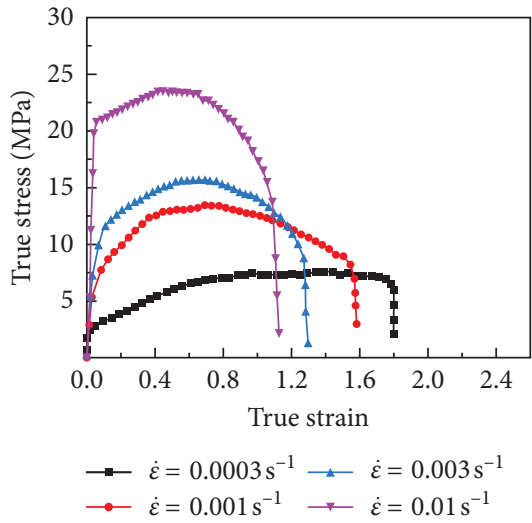

(b)

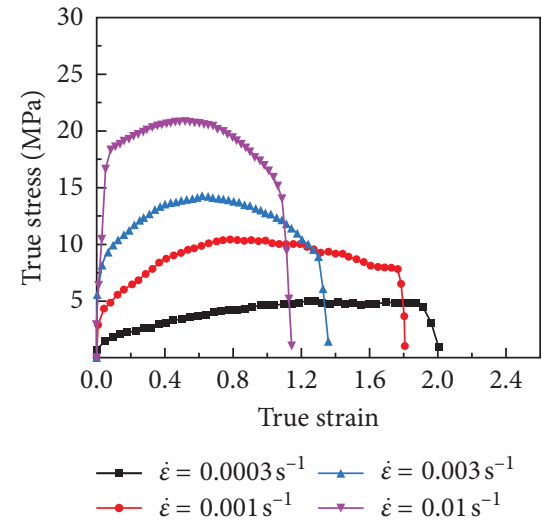

(c)

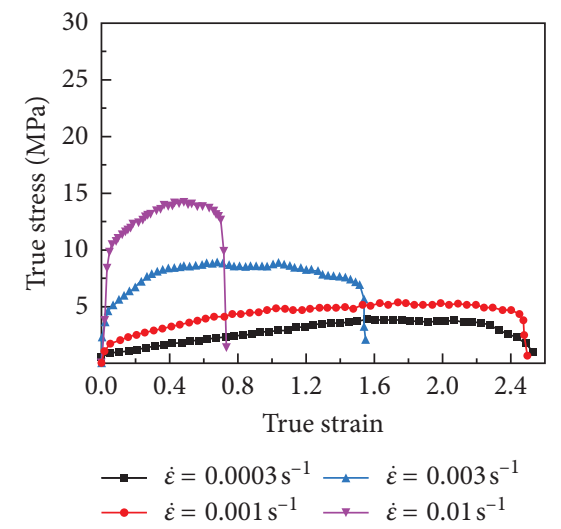

(e)

FIgURE 1: True stress-true strain curves of $7 \mathrm{~B} 04 \mathrm{Al}$ alloy after superplastic deformation under different parameters: (a) $470^{\circ} \mathrm{C}$; (b) $485^{\circ} \mathrm{C}$; (c) $500^{\circ} \mathrm{C}$; (d) $515^{\circ} \mathrm{C}$; (e) $530^{\circ} \mathrm{C}[52]$.

TABle 1: Main texture components in FCC metals.

\begin{tabular}{|c|c|c|c|c|c|}
\hline Texture & $\{h k l\}$ & $<u v w>$ & $\Phi_{1}\left({ }^{\circ}\right)$ & $\Phi\left(^{\circ}\right)$ & $\Phi_{2}\left(^{\circ}\right)$ \\
\hline Cube & $\left\{\begin{array}{lll}0 & 0 & 1\end{array}\right\}$ & $\left.<1 \begin{array}{lll}1 & 0 & 0\end{array}\right\rangle$ & 00 & 0 & 0 \\
\hline Rotated cube & $\left\{\begin{array}{lll}0 & 0 & 1\end{array}\right\}$ & $<1 \quad 10>$ & 45 & 0 & 0 \\
\hline Copper & $\left\{\begin{array}{lll}1 & 1 & 2\end{array}\right\}$ & $<1 \quad 11>$ & 90 & 35 & 45 \\
\hline Brass & $\left\{\begin{array}{lll}0 & 1 & 1\end{array}\right\}$ & $<211>$ & 35 & 45 & 0 \\
\hline Goss & $\left\{\begin{array}{lll}0 & 1 & 1\end{array}\right\}$ & $<\begin{array}{lll}1 & 0 & 0\end{array}>$ & 0 & 45 & 0 \\
\hline S & $\left\{\begin{array}{lll}1 & 2 & 3\end{array}\right\}$ & $<634>$ & 59 & 37 & 63 \\
\hline $\mathrm{R}$ & $\left\{\begin{array}{lll}1 & 2 & 4\end{array}\right\}$ & $<211>$ & 57 & 29 & 63 \\
\hline
\end{tabular}

deformation. The larger the value of strain rate sensitivity is, the greater the superplastic elongation will be. Additionally, it should be aware that $m$ constantly varies during superplastic deformation. According to Equation (3), after logarithmic transformation, strain rate sensitivity can be stated as

$$
m=\left.\frac{\partial \ln \sigma}{\partial \log \dot{\varepsilon}}\right|_{T} .
$$

Normally, the varying value of the strain rate sensitivity indicates different mechanisms of superplastic deformation. When the value of the strain rate sensitivity is around 0.3 , the main mechanism of superplastic deformation of $\mathrm{Al}$ alloys is GBS accompanied with other accommodation mechanisms (Section 4.1). When the value of the strain rate sensitivity is around 0.5 , the dominant mechanism of superplastic deformation of $\mathrm{Al}$ alloys is GBS. With increasing value of strain rate sensitivity, GBS gradually becomes the main mechanism of superplastic deformation of $\mathrm{Al}$ alloys and is responsible for the majority part of superplastic deformation of $\mathrm{Al}$ alloys.

During plastic deformation of metals, deformation activation energy $Q$ represents the energy required for the transition atoms in each mole to jump across the barrier. Essentially, superplastic deformation is a thermal activation process. Equation (6) is applied to calculate the activation energy $(Q)$, which is a critical dynamic parameter to indicate the level of difficulty of plastic deformation of materials at relatively high temperature. The values of the activation energy (Q) for different deformation mechanisms are different. During superplastic deformation, the value of $Q$ for the dislocation pipe diffusion in aluminum is $82 \mathrm{~kJ} / \mathrm{mol}$, the value of the grain-boundary sliding is $84 \mathrm{~kJ} / \mathrm{mol}$, and the value of lattice self-diffusion of pure aluminum is $142 \mathrm{~kJ} / \mathrm{mol}$ :

$$
Q=\left.\frac{R}{m} \frac{\partial \ln \sigma}{\partial(1 / T)}\right|_{\dot{\varepsilon}},
$$

where $R$ is the gas constant, $m$ is the strain rate sensitivity, $\sigma$ is the flow stress, and $T$ is the absolute temperature.

Average values of $m$ and $Q$ during superplastic deformation of different aluminum alloys are listed in Table 2. 


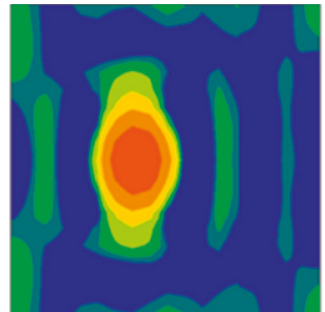

$0^{\circ}$

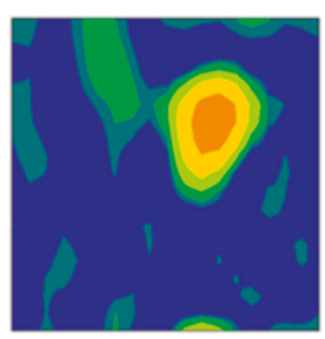

$65^{\circ}$

(a)

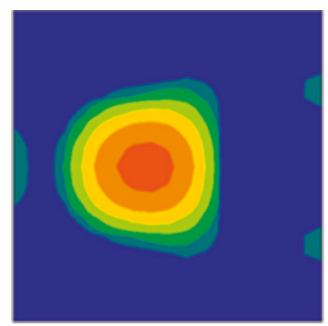

$0^{\circ}$

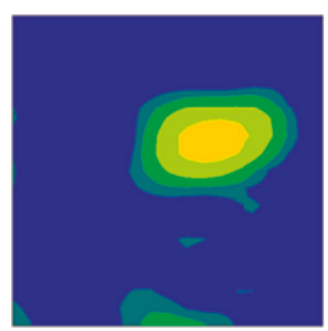

$65^{\circ}$

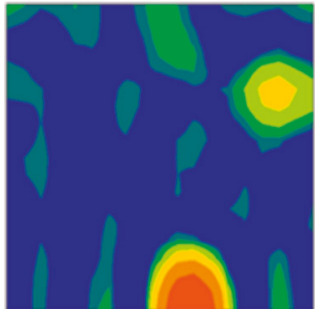

$45^{\circ}$

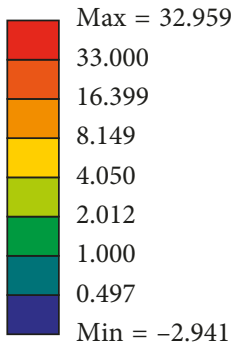

Min $=-2.941$

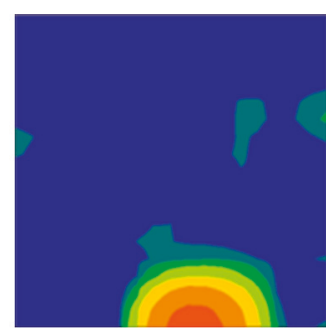

$45^{\circ}$

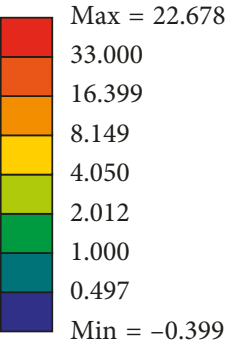

(c)

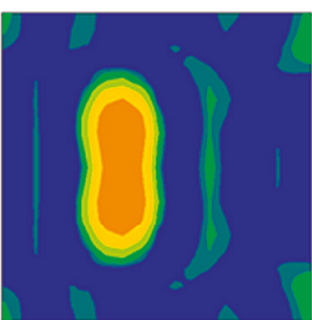

$0^{\circ}$

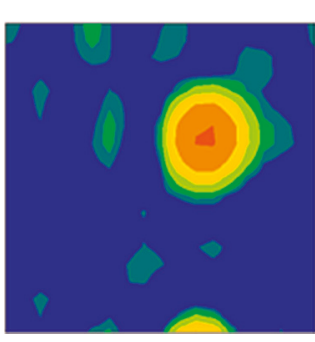

$65^{\circ}$

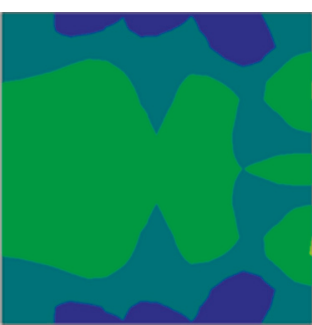

$0^{\circ}$

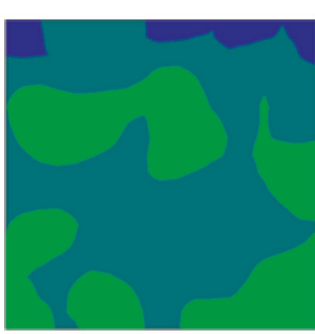

$65^{\circ}$

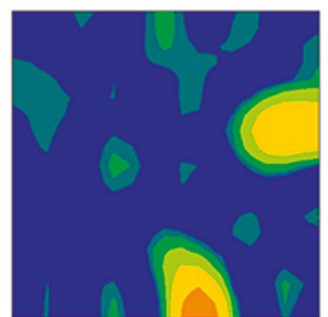

$45^{\circ}$

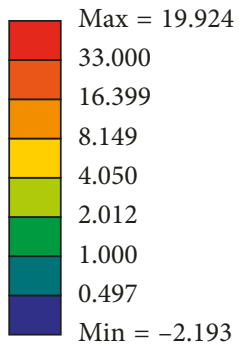

$\mathrm{Min}=-2.193$

(b)

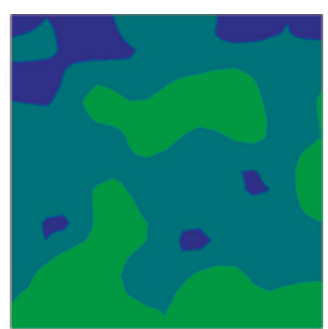

$45^{\circ}$

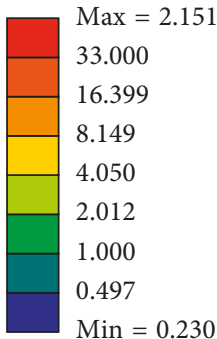

$\operatorname{Min}=0.230$

(d)

Figure 2: ODFs representative sections of the Al-Zn-Mg-0.25Sc-0.10Zr alloy deformed at $500^{\circ} \mathrm{C}$ and $1 \times 10^{-2} \cdot \mathrm{s}^{-1}$ after interrupting the tensile test at different strains: (a) $\varepsilon=0$; (b) $\varepsilon=0.69$; (c) $\varepsilon=1.10$; (d) $\varepsilon=2.40$ [42].

TABLE 2: Reference data to illustrate range and average values of $m$ and $Q$ during superplastic deformation.

\begin{tabular}{|c|c|c|c|c|c|}
\hline Alloy type & $T\left({ }^{\circ} \mathrm{C}\right)$ & Strain rate $\left(\mathrm{s}^{-1}\right)$ & $M$ & $Q(\mathrm{~kJ} / \mathrm{mol})$ & Reference \\
\hline Al-Mg-Sc-Zr & $450-525$ & $1.67 \times 10^{-3}-1 \times 10^{-1}$ & $\begin{array}{c}0.36-0.42 \\
0.39\end{array}$ & $\begin{array}{c}90-126 \\
107\end{array}$ & {$[43]$} \\
\hline $\mathrm{Al}-\mathrm{Zn}-\mathrm{Mg}-\mathrm{Sc}-\mathrm{Zr}$ & $450-500$ & $1 \times 10^{-3}-1 \times 10^{-1}$ & $\begin{array}{c}0.35-0.40 \\
0.37\end{array}$ & $\begin{array}{c}83.8-85.0 \\
84.5\end{array}$ & {$[42]$} \\
\hline $\mathrm{Al}-\mathrm{Zn}-\mathrm{Mg}-\mathrm{Sc}$ & $450-500$ & $1 \times 10^{-3}-1 \times 10^{-2}$ & $\begin{array}{c}0.46-0.51 \\
0.50\end{array}$ & $\begin{array}{c}83.8-85.6 \\
85\end{array}$ & {$[56]$} \\
\hline $\mathrm{Al}-\mathrm{Mg}-\mathrm{Sc}-\mathrm{Zr}$ & $425-500$ & $1 \times 10^{-3}-1 \times 10^{-1}$ & $\begin{array}{c}0.35-0.53 \\
0.43\end{array}$ & $\begin{array}{c}93.269-177.517 \\
143.762\end{array}$ & {$[57]$} \\
\hline Al-Mg-Li & $430-570$ & $5 \times 10^{-4}-1 \times 10^{-3}$ & $\begin{array}{c}0.41-0.85 \\
0.61\end{array}$ & - & {$[58]$} \\
\hline $\mathrm{Al}_{3} \mathrm{Ti} / 2024 \mathrm{Al}$ & $450-540$ & $0.15-1.5$ & - & 206 & {$[59]$} \\
\hline
\end{tabular}




\section{The Superplastic Behaviors of Al Alloys}

3.1. Al-Mg Alloys. Ye et al. [58, 60-67] developed a thermalmechanical process to produce fine-grained $\mathrm{Al}-\mathrm{Mg}-\mathrm{Si}$ alloy plates with the chemical composition of Al-5.2\%Mg$2.1 \% \mathrm{Li}-0.12 \% \mathrm{Zr}(\mathrm{wt} . \%)$ for superplasticity research. The uniaxial tensile tests were conducted at initial strain rates ranging from 0.01 to $0.0005 / \mathrm{s}$ in the temperature interval of $450^{\circ} \mathrm{C}-570^{\circ} \mathrm{C}$. It turned out that great elongations of $580-915 \%$ were obtained at $510^{\circ} \mathrm{C}-540^{\circ} \mathrm{C}$ and initial strain rate between $0.001 / \mathrm{s}$ and $0.0005 / \mathrm{s}$, in which the optimal elongation of about $915 \%$ occurred at a temperature of $525^{\circ} \mathrm{C}$ and an initial strain rate of $0.001 / \mathrm{s}$.

Mikhaylovskaya et al. [68] put emphasis on the different superplastic deformation behaviors of two fine-grained AA5083 alloys, with and without chromium content, at elevated temperature from $500^{\circ} \mathrm{C}$ to $560^{\circ} \mathrm{C}$ and constant strain rates of $0.0005 / \mathrm{s}, 0.001 / \mathrm{s}$, and $0.002 / \mathrm{s}$. The sigmoidal shape of the stress-strain rate curves obtained for both alloys imply that they were subjected to superplastic deformation.

Duan et al. [41] studied the superplasticity of Al-Mg$0.15 \mathrm{Sc}-0.10 \mathrm{Zr}$ alloy, using a simple thermal-mechanical processing. Their work revealed that the cold rolled alloy sheet exhibited excellent superplasticity (elongation of $\geq 800 \%$ ) at a temperature range of $450^{\circ} \mathrm{C}-500^{\circ} \mathrm{C}$ and a high strain rate range of $0.01-0.1 / \mathrm{s}$. A maximum elongation of $1579 \%$ was achieved at $475^{\circ} \mathrm{C}$ and a high strain rate of $0.05 / \mathrm{s}$.

$\mathrm{Xu}$ et al. [69] performed a research on high strain rate superplasticity of an Al-6.1Mg-0.25Sc-0.1Zr (wt.\%) alloy by original asymmetrical rolling technology. The alloy sheets were subjected to both plane strain deformation and additional shear component along the rolling direction, simultaneously, owing to the different circumferential velocities of the two rotary rolls. The studied alloy exhibited fantastic superplasticity (elongation $>1000 \%$ ) at the temperature interval of $450^{\circ} \mathrm{C}-500^{\circ} \mathrm{C}$ and relatively high strain rates ranging from $0.01 / \mathrm{s}$ to $0.25 / \mathrm{s}$. The highest ductility of $3200 \%$ is achieved at $500^{\circ} \mathrm{C}$ and $0.05 / \mathrm{s}$. Compared with the same materials produced by traditional rolling, asymmetrical rolling technology can increase the optimum strain rate up to 10 times.

$\mathrm{Li}$ et al. [43] dealt with the superplastic behavior of an $\mathrm{Al}$ $5.8 \mathrm{Mg}-0.4 \mathrm{Mn}-0.25 \mathrm{Sc}-0.1 \mathrm{Zr}$ (wt.\%) alloy at the temperature interval of $450^{\circ} \mathrm{C}-525^{\circ} \mathrm{C}$ and strain rates ranging from $0.00167 / \mathrm{s}$ to $0.1 / \mathrm{s}$. Experimental results showed that the alloys exhibited nice elongation, ranging from $230 \%$ to $740 \%$, and the maximum elongation of $740 \%$ was achieved at $500^{\circ} \mathrm{C}$ and the initial strain rate of $0.00667 / \mathrm{s}$.

3.2. Al-Li Alloys. Xinming Zhang et al. [70-76] did superplastic investigation on $2 \mathrm{~A} 97 \mathrm{Al}-\mathrm{Li}$ alloy at the temperature range of $480^{\circ} \mathrm{C}-490^{\circ} \mathrm{C}$ and strain rates of $0.001-0.0025 / \mathrm{s}$. The results indicated that the alloy exhibited promising elongation, ranging from $600 \%$ to $850 \%$, and the highest elongation of $850 \%$ was achieved at $490^{\circ} \mathrm{C}$ and the initial strain rate of $0.002 / \mathrm{s}$.

Zhang et al. [55] conducted superplastic investigation on $5 \mathrm{~A} 90 \mathrm{Al}-\mathrm{Li}$ alloy at the temperature range of $450^{\circ} \mathrm{C}-500^{\circ} \mathrm{C}$ and strain rate of $0.0003-0.0018 / \mathrm{s}$. The results indicated that the alloy exhibited promising elongation, ranging from $310 \%$ to $1050 \%$, and the greatest elongation of $1050 \%$ was achieved at $475^{\circ} \mathrm{C}$ and the initial strain rate of $0.0008 / \mathrm{s}$.

3.3. Al-Zn-Mg Alloys. Wang et al. [77-86] performed superplastic investigation on the friction stir processed (FSP) $\mathrm{Al}-\mathrm{Zn}-\mathrm{Mg}-\mathrm{Cu}$ alloy at the temperature of $500^{\circ} \mathrm{C}-535^{\circ} \mathrm{C}$ and a high strain rate of $0.01 / \mathrm{s}$. The results proved that the FSP $\mathrm{Al}-\mathrm{Zn}-\mathrm{Mg}-\mathrm{Cu}$ alloy possesses excellent thermal stability even up to incipient melting temperature; furthermore, a highest elongation of $3250 \%$ was obtained at $535^{\circ} \mathrm{C}$ and $0.01 / \mathrm{s}$.

Mikhaylovskaya et al. [87] compared the superplastic deformation behavior of two aluminum AA7XXX alloys with $\mathrm{Sc}$ and $\mathrm{Zr}$ additions distinguished by the presence and absence of coarse eutectic $\mathrm{Al}_{9} \mathrm{FeNi}$ particles. The experimental results were that the alloy with $\mathrm{Sc}(0.1 \%)$ and $\mathrm{Zr}$ (0.2\%) additions and eutectic $\mathrm{Al}_{9} \mathrm{FeNi}$ particles (a size of $1.8 \mu \mathrm{m}$ and a volume fraction of 0.085 ) exhibits high superplasticity (elongation of $300 \%-915 \%$ ) at the temperature interval of $400^{\circ} \mathrm{C}-500^{\circ} \mathrm{C}$ and strain rates ranging from $0.005 / \mathrm{s}$ to $0.01 / \mathrm{s}$. The highest ductility of $915 \%$ is achieved at $480^{\circ} \mathrm{C}$ and $0.01 / \mathrm{s}$. On the contrary, the alloy with same Sc $(0.1 \%)$ and $\mathrm{Zr}(0.2 \%)$ additions and without $\mathrm{Al}_{9} \mathrm{FeNi}$ particles did not elongate more than $340 \%$, and there is no superplasticity at high strain rates (more than $0.01 / \mathrm{s}$ ).

The superplastic performances of the abovementioned aluminum alloys are listed in Table 3.

3.4. Aluminum Matrix Composites. A great number of researchers $[90,91]$ have been constantly focusing on developing high strain rate and low temperature superplastic formation technology for aluminum matrix composites. The most recent works about superplasticity of aluminum matrix composites are listed in Table 4.

\section{Discussion}

4.1. Mechanisms of Superplastic Deformation. Enormous efforts and researches have been done on what is the exact mechanism of superplastic deformation, yet there is not a unified conclusion.

Generally speaking, superplastic deformation is mainly controlled by three mechanisms: grain-boundary sliding (GBS), dislocation slip/creep, and diffusion creep or directional diffusional flow [53]. Meanwhile, superplastic deformation is accompanied by various processes, for instance, grainboundary migrations and static/dynamic grain growth, grain rotation $[80,99]$, recovery, recrystallisation, and polygonisation $[87,100,101]$. It is commonly accepted that GBS at low strain rates and creep by glide plus climb, also named slip creep, at high strain rates are the dominant controlling mechanisms that operate during high-temperature deformation of fine-grained metallic materials [102-104]. The contribution of GBS in the total strain varies with different $\mathrm{Al}$ alloys.

The work of Duan [105], Liu [106], and Cao [107] showed that GBS is a predominant mechanism of superplastic deformation of $\mathrm{Al}-\mathrm{Zn}-\mathrm{Mg}-\mathrm{Sc}(\mathrm{Zr})$ alloys. Bate [108] 
TABLE 3: Deformation conditions of optimal superplastic elongation of $\mathrm{Al}$ alloys.

\begin{tabular}{|c|c|c|c|c|}
\hline $\mathrm{Al}$ alloys (wt.\%) & Temperature $\left({ }^{\circ} \mathrm{C}\right)$ & Strain rate $\left(\mathrm{s}^{-1}\right)$ & Elongation (\%) & Reference \\
\hline Al-5.2Mg-2.1Li-0.12Zr & 525 & 0.001 & 915 & {$[58]$} \\
\hline Al-Mg-0.15Sc-0.10Zr & 475 & 0.05 & 1579 & {$[41]$} \\
\hline $\mathrm{Al}-6.1 \mathrm{Mg}-0.25 \mathrm{Sc}-0.1 \mathrm{Zr}$ & 500 & 0.05 & 3200 & {$[69]$} \\
\hline $\mathrm{Al}-5.8 \mathrm{Mg}-0.4 \mathrm{Mn}-0.25 \mathrm{Sc}-0.1 \mathrm{Zr}$ & 500 & 0.00667 & 740 & {$[43]$} \\
\hline $\mathrm{Al}-5.3 \mathrm{Mg}-2.1 \mathrm{Li}-0.11 \mathrm{Zr}$ & 475 & 0.0008 & 1050 & {$[55]$} \\
\hline $\mathrm{Al}-5 \mathrm{Mg}-0.2 \mathrm{Sc}$ & 520 & 0.056 & 2300 & {$[88]$} \\
\hline $\mathrm{Al}-3 \mathrm{Mg}-0.2 \mathrm{Sc}$ & 400 & 0.033 & 2280 & [89] \\
\hline $\mathrm{Al}-3.8 \mathrm{Cu}-1.4 \mathrm{Li}(2 \mathrm{~A} 97)$ & 490 & 0.002 & 850 & {$[76]$} \\
\hline $\mathrm{Al}-5.85 \mathrm{Zn}-2.56 \mathrm{Mg}-1.89 \mathrm{Cu}$ & 535 & 0.01 & 3250 & {$[86]$} \\
\hline $\mathrm{Al}-6 \mathrm{Zn}-2.3 \mathrm{Mg}-1.7 \mathrm{Cu}(7 \mathrm{~B} 04)$ & 530 & 0.0003 & 1105 & {$[52]$} \\
\hline $\mathrm{Al}-5.6 \mathrm{Zn}-2.2 \mathrm{Mg}-1.5 \mathrm{Cu}(7475)$ & 515 & 0.0005 & 590 & {$[46]$} \\
\hline Al-5.41Zn-1.9Mg-0.25Sc-0.1Zr & 500 & 0.01 & 1523 & {$[76]$} \\
\hline $\mathrm{Al}-5.36 \mathrm{Zn}-1.9 \mathrm{Mg}-0.1 \mathrm{Sc}-0.1 \mathrm{Zr}$ & 500 & 0.005 & 1050 & {$[56]$} \\
\hline Al- $5.4 \mathrm{Zn}-2 \mathrm{Mg}-0.25 \mathrm{Sc}-0.1 \mathrm{Zr}$ & 200 & 0.01 & 539 & {$[57]$} \\
\hline
\end{tabular}

TABLE 4: Deformation conditions of optimal superplastic elongation of aluminum matrix composites.

\begin{tabular}{|c|c|c|c|c|}
\hline Composites & Temperature $\left({ }^{\circ} \mathrm{C}\right)$ & Strain rate $\left(\mathrm{s}^{-1}\right)$ & Elongation (\%) & Reference \\
\hline 20wt. $\% \mathrm{Si}_{3} \mathrm{~N}_{4 \mathrm{P}} / 5052$ & 545 & 0.001 & 700 & {$[92]$} \\
\hline 10wt.\%SiC $\mathrm{P} / 2024$ & 480 & 0.001 & 345 & {$[93]$} \\
\hline 20wt. $\% \mathrm{Si}_{3} \mathrm{~N}_{4 \mathrm{P}} / 2124$ & 510 & 0.04 & 840 & {$[94]$} \\
\hline 15 wt.\%SiC $/$ IN9021 & 550 & 0.005 & 610 & {$[95]$} \\
\hline 17.8wt. $\% \mathrm{SiC}_{\mathrm{P}} / 2124$ & 490 & 0.083 & 425 & [96] \\
\hline 15 wt. $\% \mathrm{SiC}_{\mathrm{P}} / 6 \mathrm{~A} 02$ & 560 & 0.00089 & 250 & {$[97]$} \\
\hline 12 wt. $\% \mathrm{SiC}_{\mathrm{P}} / 5052$ & 550 & 0.0011 & 405 & {$[98]$} \\
\hline 5wt.\% $\% \mathrm{Al}_{3} \mathrm{Ti} / 2024$ & 510 & 0.15 & 640 & [59] \\
\hline
\end{tabular}

concluded that the major superplastic deformation mechanism of Al-6Cu-0.4Zr alloy may be an intragranular dislocation slip. Katsas [109] considered that dynamic recrystallisation process results in the superplastic deformation of Al-1Zr alloy. Sotoudeh [110] and Bricknell [111] believed that diffusion creep is the main superplasticity mechanism of "supral type" alloys with banded microstructure. del Valle et al. [112] concluded that $\mathrm{Al}$ alloys that were composed of fine-equiaxed grains at the start of the superplastic test deformed mainly by GBS at low strain rate with only small evidence of dislocation activity and slip creep was the controlling mechanism at high strain rate superplastic deformation. The research of Wang et al. [86] indicated that the presence of a liquid phase because high experimental temperature plays a vital role in the extraordinary elongation of the alloy by relaxing the stress concentration and suppressing the the appearance of cavities during deformation. Jiao [59] also supported that a certain amount of liquid phase during superplastic deformation can properly enhance the superplasticity of aluminum alloys. Meanwhile, Johannes and Mishra [113] concluded that fiber (whisker) formation (Figure 3) was the evidence of the existence of liquid phases along grain boundaries. Furthermore, Duan et al. [56] thought the existence of fiber as an indirect evidence for GBS.

Commonly, fine and equiaxed grains are typical features of superplastic materials. It is fully established by a great number of theories and researches that grainboundary sliding is the dominant reason that fine-grained materials are able to develop superplastic deformation.
During deformation, materials migration and grainboundary sliding happen simultaneously in order to assure intergranular accommodation. Moreover, it is necessary for another mechanism to accommodate stress concentration resulting from GBS. There are two main accommodation mechanisms for GBS, diffusion creep and dislocation sliding.

After a thorough research, Ashby and Verrall proposed the classic mechanism theory of GBS with diffusion creep for superplastic deformation, the theoretical model of which is shown in Figure 4. The Ashby-Verrall model (Figure 3) interprets how the equiaxed grains move by means of GBS. Though the shape of grains stay the same after sliding,the overall morphology changes, which is in agreement with macroelongation. Moreover, Ashby and Verrall explained that the strain difference between the initial and final circumstances is accommodated by grain-boundary diffusion and volume diffusion, as well as the ability of grain-boundary diffusion is much stronger than that of volume diffusion.

Currently, there are three models for theories of grainboundary sliding accommodated by dislocation sliding, which are introduced in Table 5.

Additionally, it is considered that the mechanism of superplastic deformation for $\mathrm{Al}$ alloys is related to the microstructure status of the alloys prior to the deformation. After TMP, there are two ways to obtain fine grains for the alloys, which would result in different mechanisms of superplastic deformation. On one hand, if the thermalmechanically treated alloys are subjected to recrystallisation annealing treatment, the main deformation mechanism of superplastically deformed alloys is concurrently controlled by 


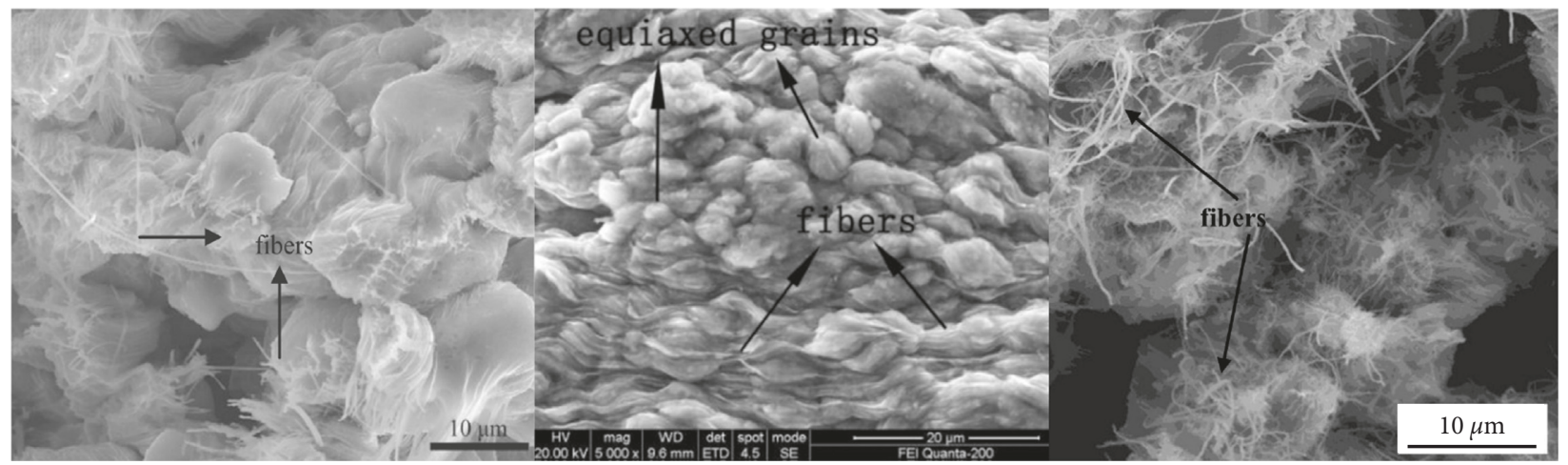

FIGURE 3: SEM image of fracture morphology of superplastically deformed $\mathrm{Al}$ alloys $[41,42,57]$.
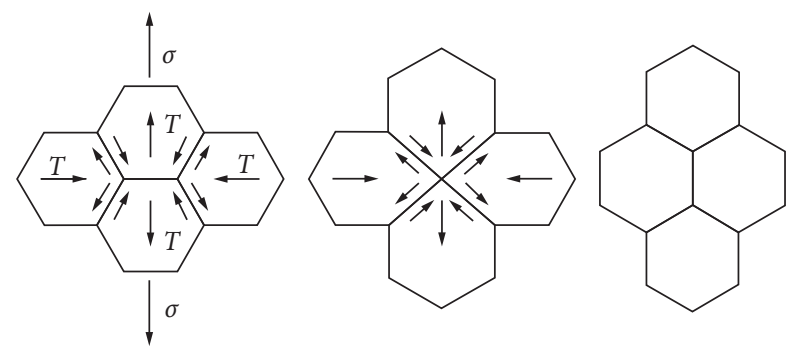

Figure 4: The Ashby-Verrall theoretical model for superplastic deformation. (a) Initial. (b) Intermediate. (c) Final.

both grain-boundary sliding (GBS) and accompanied accommodation mechanism which include dislocation motion [116-118], creep diffusion [119], and liquid phase [86], aiming to relax the stress concentration. On the other hand, when the thermal-mechanically treated alloys directly experience superplastic deformation, during the primary stage of deformation, the mechanism is controlled by deformationinduced continuous recystallisation (DICR) due to the occurrence of dynamic recrystallisation. Subsequently, the superplastic deformation mechanism is similar to static recrystallisation, after dynamic recrystallisation is completed.

\subsection{Factors Affecting Superplastic Deformation Behavior}

\subsubsection{Temperature of Superplastic Deformation.} Fundamentally speaking, superplasticity is a thermally activated phenomenon; therefore, the deformation temperature is a crucial factor. It is commonly accepted that there is a basic requirement for the $\mathrm{Al}$ alloys to exhibit superplasticity, which is that the deformation temperature shall be more than $0.5 T_{\mathrm{m}}$ (melting temperature). As the temperature keeps rising, the viscous forces within grain boundaries gradually reduce and grain boundaries become more and more unstable. As a result, the grain boundary begins to slide with relative ease, which makes the tensile test sample to show better elongation. However, if the temperature is too high, grain boundaries are excessively softened and grainboundary binding force dramatically decreases, which lead to less elongations. It can be seen from Figure 5 that the superplastic elongations are intensively changed with different temperatures of superplastic deformation and there is an optimal temperature for each kind of aluminum alloy.
Zhang et al. [52] found out that superplastic property of $\mathrm{Al}$ alloys started to decline and became insensitive to deformation temperature when the alloys were superplastically deformed at relatively high strain rates.

4.2.2. Strain Rates of Superplastic Deformation. Besides deformation temperature, stain rates also could notably influence the superplasticity of $\mathrm{Al}$ alloys. As shown in Equation (3), the true stress $\sigma$ is highly dependent on the strain rate $\dot{\varepsilon}$, so it also means that the superplastic deformation process of $\mathrm{Al}$ alloys is significantly affected by the strain rate.

Researches $[120,121]$ indicate that one precondition of superplasticity is that the stain rates should be in the range of $10^{-4}-10^{-1} / \mathrm{s}$. Figure 6 shows the correlation between superplastic elongation and varying initial strain rates at different temperatures of different $\mathrm{Al}$ alloys. It can be seen that relatively low strain rates are in favor of better superplasticity. Deformed at lower initial strain rates, the $\mathrm{Al}$ alloys exhibit an extended strain-hardening phenomenon and decreased strain-hardening rates due to dislocation relaxation triggered by accommodation mechanisms of GBS. At the same time, the microstructure of $\mathrm{Al}$ alloys after superplastic deformation is partially determined by strain rates. Low strain rates could result in coarseness of the microstructure ascribed to recovery and recrystallisation processes. Better superplasticity resulting from relatively low strain rates comes at a price of great amount of time, which strongly restricts further application of superplastic deformation of $\mathrm{Al}$ alloys. Consequently, high strain rate superplasticity (HSRSP) [122-127], which can not only dramatically reduce the consuming time but also develop high superplasticity, is attracting more and more attention.

4.2.3. Precipitates Particles. Prior to superplastic deformation, particles with different size, locations, and shapes are distributed in the grains and at the boundaries, which will play a very important role during superplasticity.

By adding a few amount of trace element, high density of coherent fine precipitates $\left(\mathrm{Al}_{3}(\mathrm{Zr}, \mathrm{Sc}), \sim 30 \mathrm{~nm}\right.$ [128-131]; $\mathrm{Al}_{6}(\mathrm{Mn}, \mathrm{Cr}), 38 \pm 7 \mathrm{~nm}$ [68]) are formed and dispersed both at grain boundaries and within the grain interiors, which will strongly retard the grain growth during 
TABLE 5: Three models for theories of grain-boundary sliding accommodated by dislocation sliding.

\begin{tabular}{|c|c|c|}
\hline Models & $\begin{array}{l}\text { Schematic illustration of the mechanism } \\
\text { of superplasticity }\end{array}$ & Introduction of the models \\
\hline $\begin{array}{l}\text { Ball-Hutchison } \\
\text { model [114] }\end{array}$ & $\begin{array}{l}\text { Easy grain boundary } \\
\text { sliding plane }\end{array}$ & $\begin{array}{l}\text { During deformation, grain boundaries are properly aligned } \\
\text { and slide as groups. When the sliding is blocked by other } \\
\text { grains, the local stresses would result in dislocation in the } \\
\text { blocking grain, piling up at the opposite grain boundary until } \\
\text { the back stress stops further generation of dislocation. The } \\
\text { piled up dislocations could climb into and along the grain } \\
\text { boundary. Thus, grain-boundary sliding, which is governed by } \\
\text { the kinetics of climb along grain boundary to annihilation } \\
\text { areas, is feasible due to the constant replacement of the } \\
\text { dislocation. }\end{array}$ \\
\hline $\begin{array}{l}\text { Mukherjee } \\
\text { model [115] }\end{array}$ & & $\begin{array}{l}\text { The model elaborates dislocation accommodated sliding } \\
\text { mechanism of single grain. Dislocations are generated at } \\
\text { scraggy surfaces of grain boundaries. The alignment } \\
\text { mechanism of the generated dislocations is the same as that of } \\
\text { the Ball-Hutchison model. }\end{array}$ \\
\hline $\begin{array}{l}\text { Gifkins } \\
\text { model [116] }\end{array}$ & $\begin{array}{c}\text { Grain B } \\
\text { New } \\
\text { dislocation }\end{array}$ & $\begin{array}{l}\text { Gifkins described grain-boundary sliding and accommodation } \\
\text { process as grain-boundary dislocation motion and proposed } \\
\text { the core-mantle model. Grain-boundary sliding around grain } \\
\text { triple junctions is accommodated by generation of new } \\
\text { dislocation and their climbing along the boundaries. } \\
\text { Dislocation motion is constrained to occur at grain boundary } \\
\text { and mantle area rather than in the core of grain. According to } \\
\text { the model, grains are able to slide by switching places in three- } \\
\text { dimensional space. }\end{array}$ \\
\hline
\end{tabular}

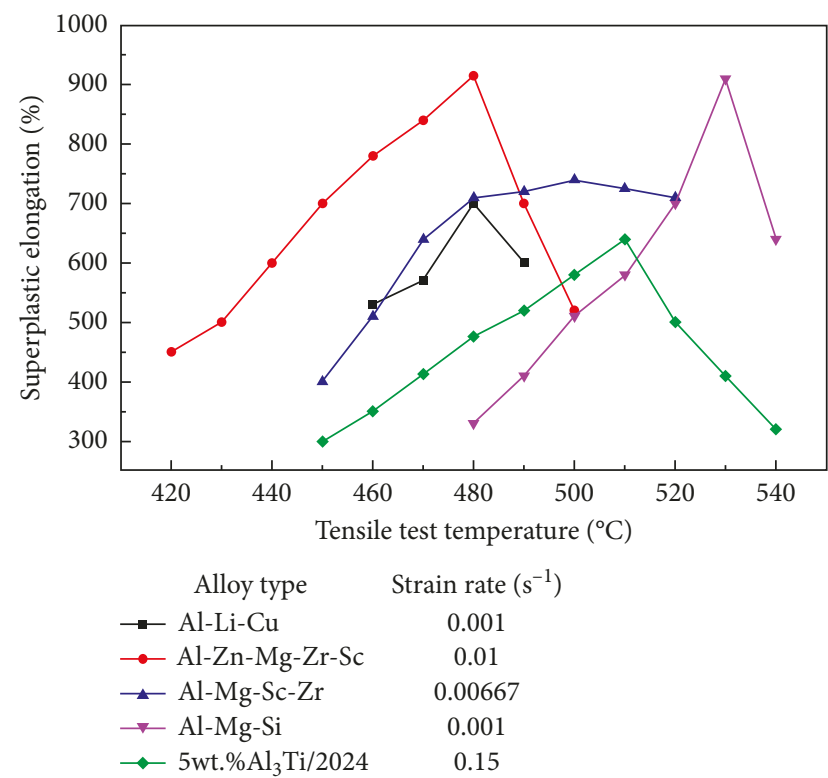

FIGURE 5: Variation of superplastic elongations of different $\mathrm{Al}$ alloys with initial strain rates at various temperatures.

recrystallisation and inhibit the movement of grain boundaries, subgrain boundaries, and dislocation by the Zener pinning effect (Figure 7). Furthermore, the stability of cavity can be partially attributed to additional interfacial energy of $\mathrm{Al}_{3}(\mathrm{Zr}, \mathrm{Sc})$ particles.

Besides nanoscale particles, there are also existence of other coarse particles $\left(\mathrm{Al}_{9} \mathrm{FeNi}, \sim 1.8 \mu \mathrm{m}\right.$, Figure 8 [87] $)$ that affect superplastic deformation. These coarse particles can form extensive deformation zones during rolling or SPD process, which can accelerate nucleation at preheating and at superplastic deformation ascribed to particles stimulated nucleation (PSN) and lead to grain refinement.

In addition, the presence of particle-depleted zones (PDZs) associated with diffusion creep is often detected in the Al alloys with uniform distribution of nanosized particles during superplastic deformation. The PDZ is often considered to facilitate the total elongation of $\mathrm{Al}$ alloys during SPF.

4.2.4. Thermal-Mechanical Processing. As stated in Section 1.2, thermal-mechanical processing plays a vital pole for $\mathrm{Al}$ alloys to obtain superplasticity. Even the alloys with experimentally approximate composition, such as Al-5.8Mg$0.4 \mathrm{Mn}-0.25 \mathrm{Sc}-0.10 \mathrm{Zr}$ [43] and Al-6.10Mg-0.3Mn-0.25Sc$0.10 \mathrm{Zr}$ [69], may exhibit superplasticity with huge difference, simply owing to distinguished thermal-mechanical processes. Both the elongations of the Al-5.8Mg-0.4Mn$0.25 \mathrm{Sc}-0.10 \mathrm{Zr}$ and $\mathrm{Al}-6.10 \mathrm{Mg}-0.3 \mathrm{Mn}-0.25 \mathrm{Sc}-0.10 \mathrm{Zr}$ alloys sample were tested at the temperatures ranging from $450^{\circ} \mathrm{C}$ to $475^{\circ} \mathrm{C}$ and at strain rates of $0.005 / \mathrm{s}$ to $0.1 / \mathrm{s}$, however, 

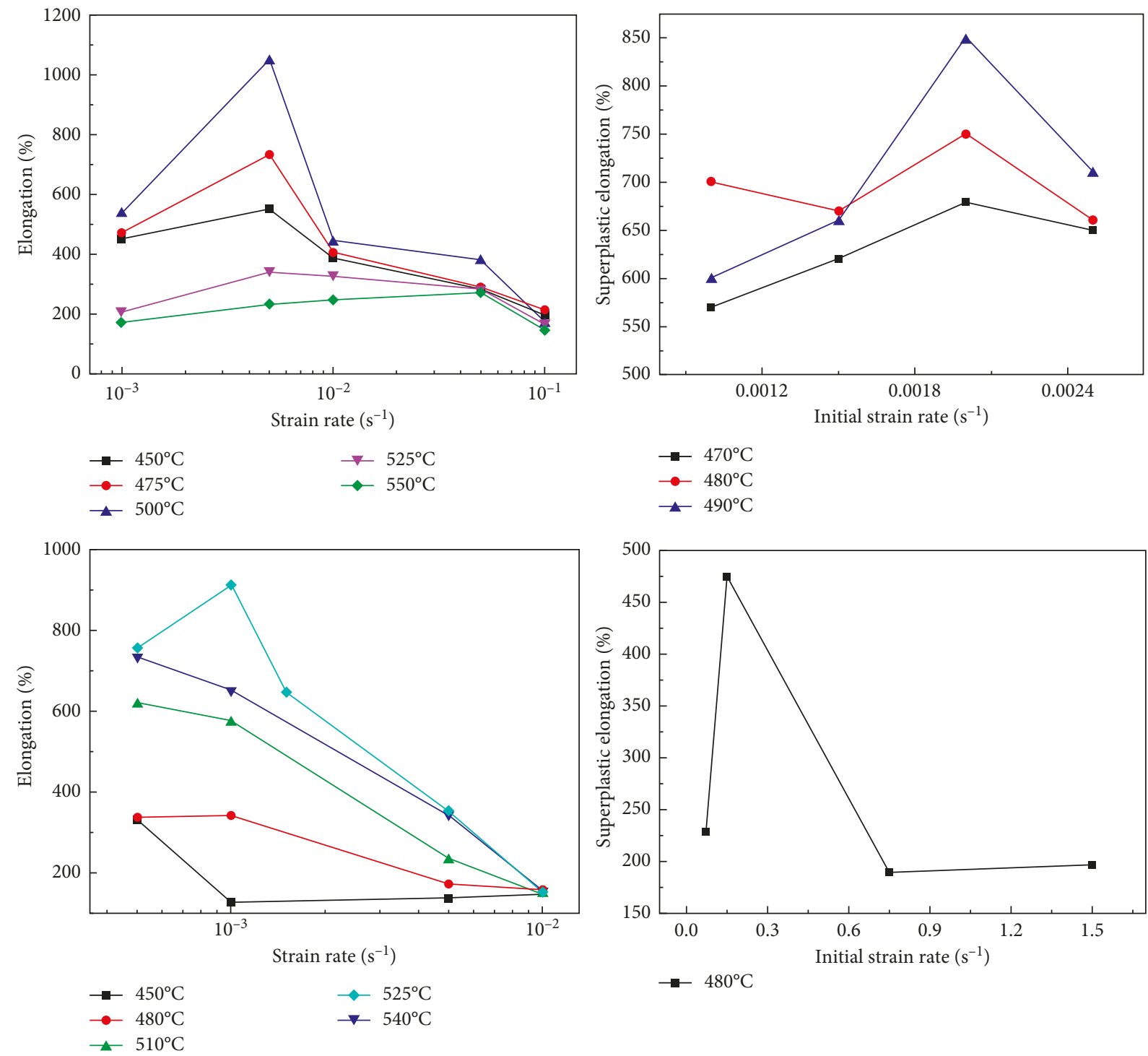

Figure 6: Variation of superplastic elongations of different $\mathrm{Al}$ alloys with varying initial strain rates at various temperatures. (a) $\mathrm{Al}-\mathrm{Zn}-\mathrm{Mg}$ Sc-Zr [56]; (b) Al-Li-Cu; (c) Al-Mg-Si [47]; (d) 5wt.\%Al 3 Ti/2024.

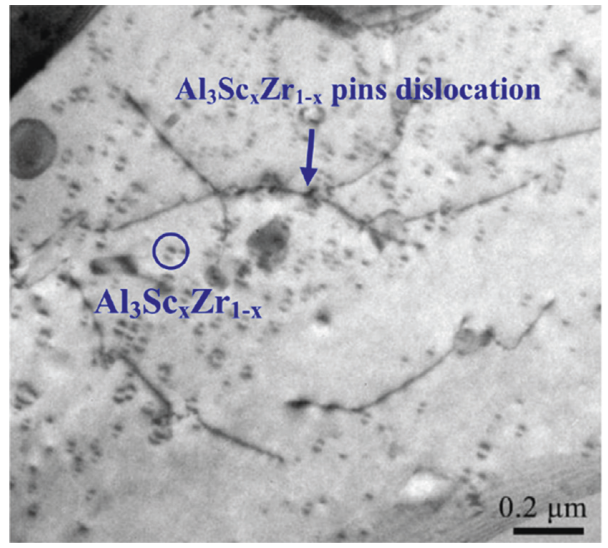

(a)

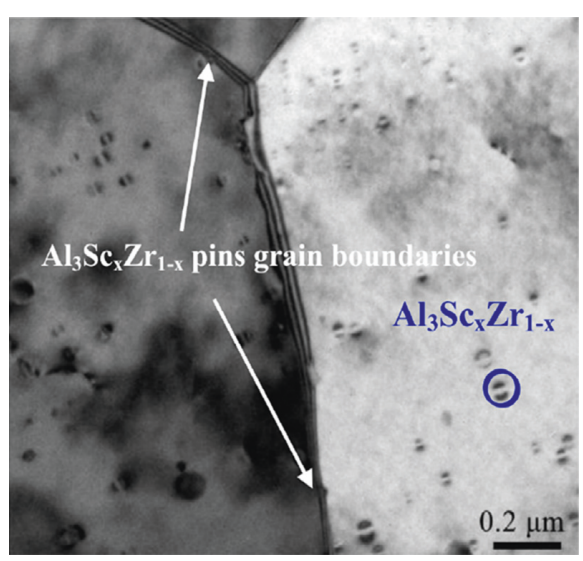

(b)

Figure 7: Continued. 


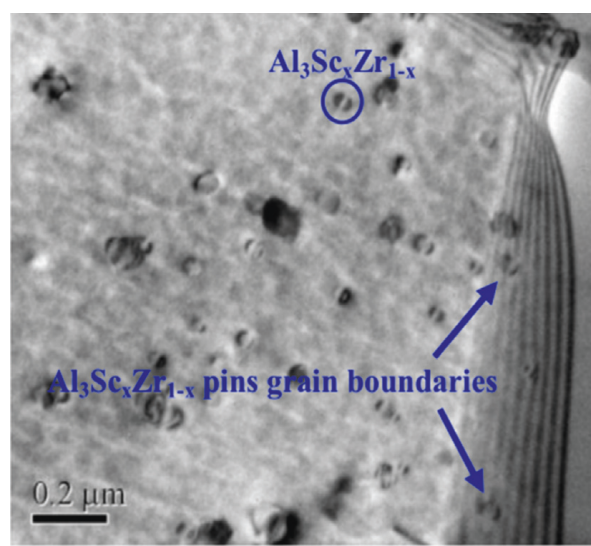

(c)

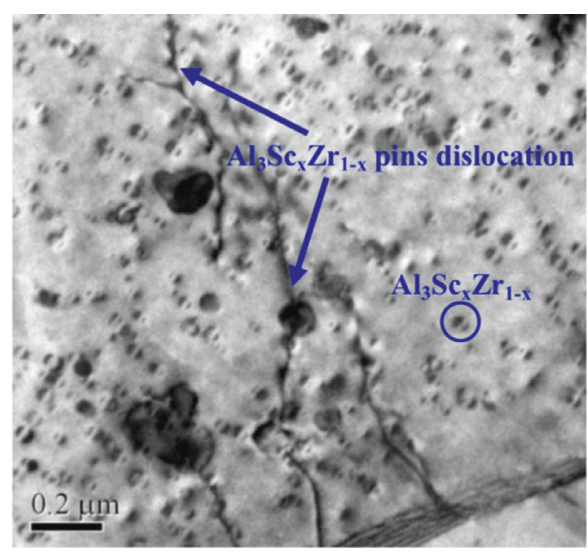

(d)

FIgURE 7: TEM microstructures of superplastically deformed Al-Zn-Mg-Sc-Zr alloy [42, 56].

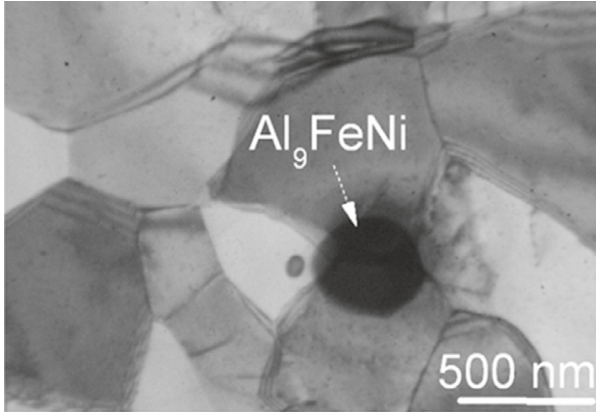

(a)

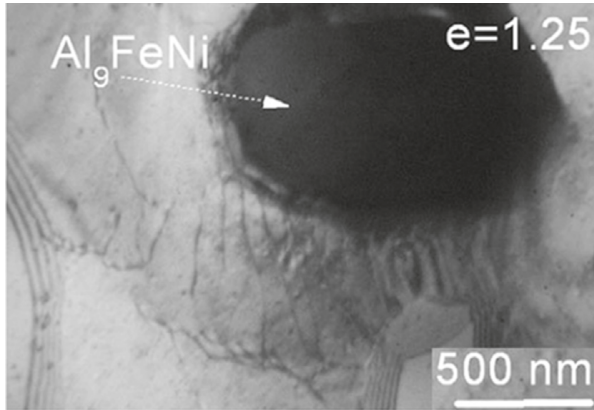

(b)

Figure 8: TEM microstructures of Al-Zn-Mg-Sc-Zr alloy: (a) 20 minutes annealed at $480^{\circ} \mathrm{C}$; (b) strain of 1.25 [87].

subjected to different thermal-mechanical processes, simple rolling and asymmetrical rolling, respectively (please check $[43,69]$ for details).

Figure 9 shows the comparison of maximum elongations of the two Al-Mg-Mn-Sc-Zr alloys under 4 tested temperatures of all tested stain rates. It is well established that the asymmetrical rolled alloy. The maximum elongations of asymmetrical rolled $\mathrm{Al}-\mathrm{Mg}-\mathrm{Mn}-\mathrm{Sc}-\mathrm{Zr}$ alloy is at least 3.1 times that of simple rolled Al-Mg-Mn-Sc-Zr alloy.

\subsection{Recovery and Recrystallisation. As described in Section} 2.2 , recovery and recrystallisation are of great importance in structural softening mechanism of $\mathrm{Al}$ alloys. Owing to high $\mathrm{SFE}$ of $\mathrm{Al}$ alloys, dynamic recovery is even more important to the softening process. Therefore, the following sections illustrate the softening process caused by recovery and recrystallisation in detail.

4.3.1. Dynamic Recovery. High density of defects (vacancies and dislocations) is generated and accumulated in the microstructure of plastic deformed $\mathrm{Al}$ alloys. High SFE and solute strengthening effect work together to make $\mathrm{Al}$ alloys undergo dynamic recovery mechanisms, which include (a) annihilation resulting in neutralization of dislocation dipoles and reduction in dislocation density,

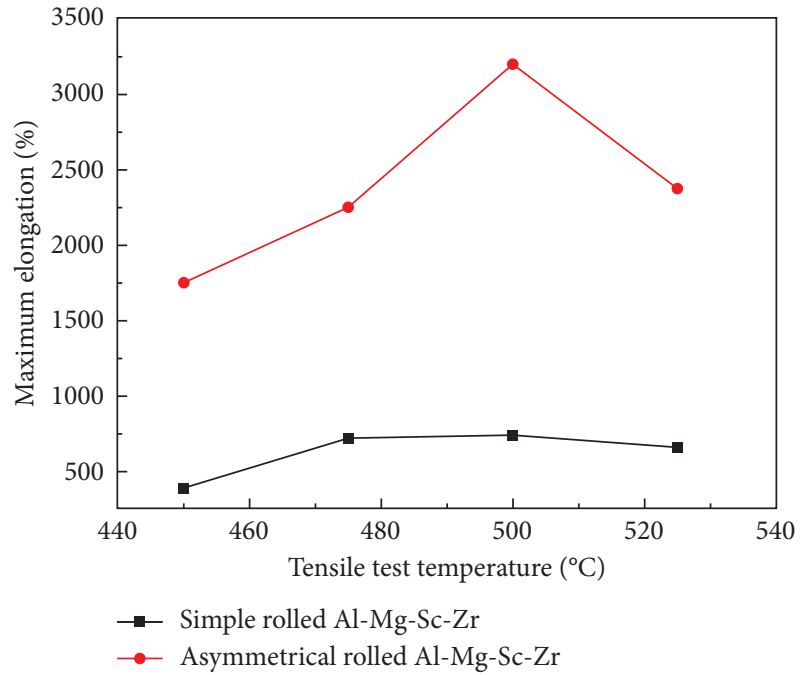

Figure 9: Comparison of maximum elongations of the two Al-Mg$\mathrm{Mn}-\mathrm{Sc}-\mathrm{Zr}$ alloys under 4 tested temperatures of all tested stain rates.

(b) polygonisation which involves systemic organization of randomly oriented dislocation into more stable microstructural elements called cells, and (c) proliferation of cells into fully developed subgrains [18]. Because 


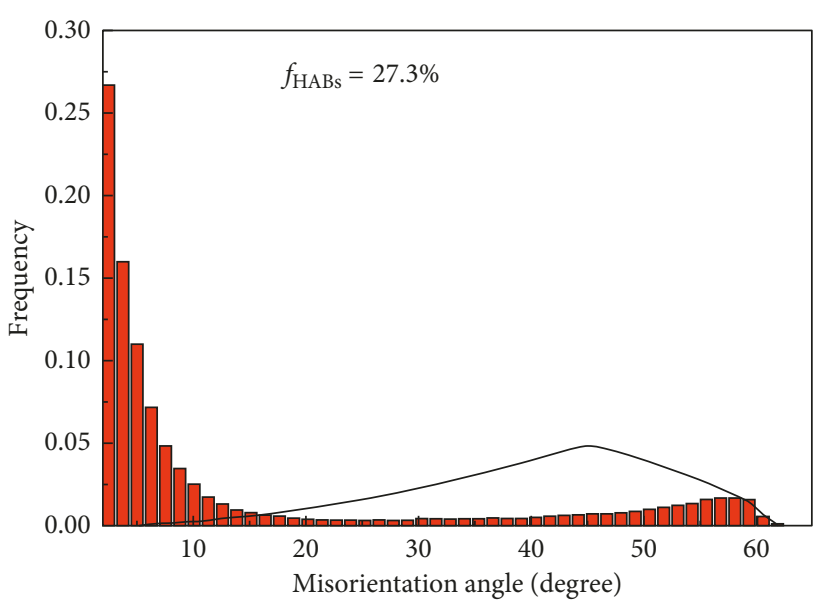

(a)

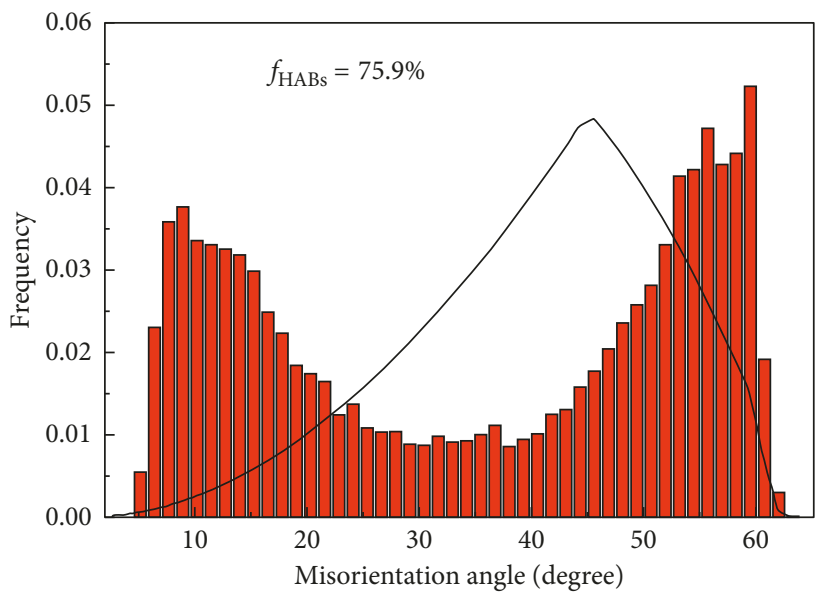

(c)

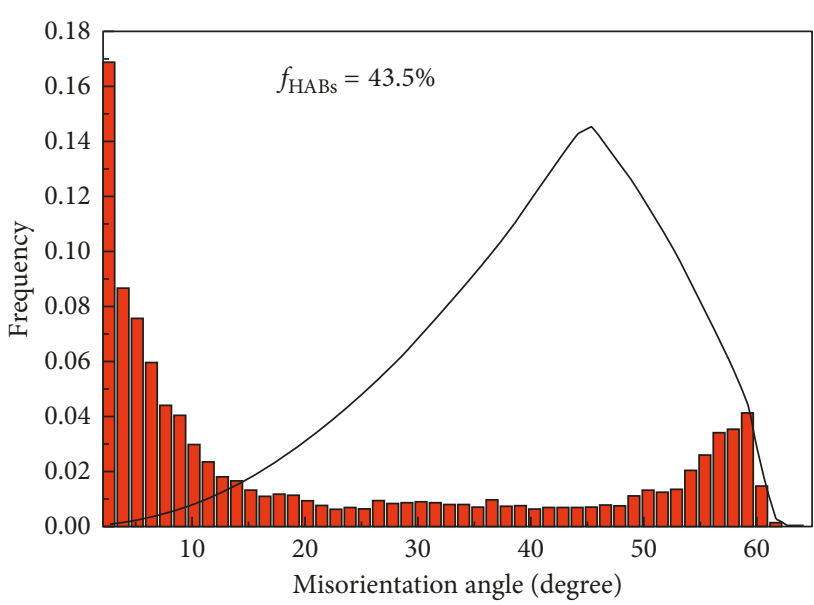

(b)

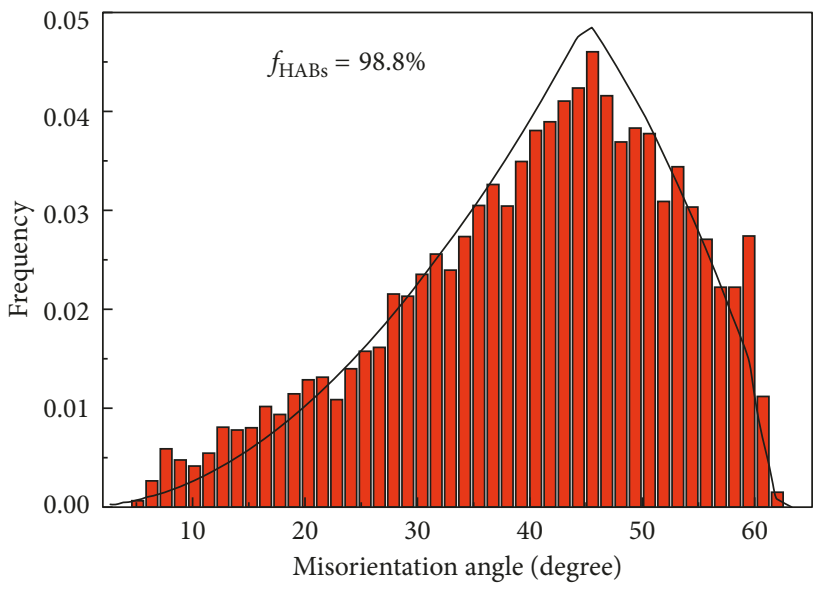

(d)

FIGURe 10: Misorientation angle distribution of the Al-Zn-Mg-0.25Sc-0.1Zr alloy deformed at $500^{\circ} \mathrm{C}$ and $1 \times 10^{-2} \cdot \mathrm{s}^{-1}$ after interrupting the tensile test at different strains: (a) $\varepsilon=0$; (b) $\varepsilon=0.69$; (c) $\varepsilon=1.10$; (d) $\varepsilon=2.40$ [42].

of work hardening, tangled microstructure is formed and transformed into an ordered one by rearrangement of dislocations into micronscale entities called cells. Densly tangled dislocations are located along the boundaries of the cells, while less dislocations are found within the cell interiors resulting from annihilation of the internal dislocations. Subsequently, the cell boundaries turn into structured subgrain boundaries with higher misorientation.

4.3.2. Deformation-Induced Continuous Recrystallisation. If the alloy sheets subjected to severe rolling/SPD process are directly superplastically deformed without static recrystallisaion annealing, it is the fibrous structure rather than equiaxed grain structure that participate in the superplastic deformation. Thus, there are two stages existing during superplastic deformation, according to structure transformation. The initial microstructure of the deformed $\mathrm{Al}$ alloys consists of a large amount of LABs, which are not favorable for GBS because of their low misorientations, while it is well proved that HABs are desired microstructure for superplastic flow by GBS $[132,133]$. In the first stage, when the superplastic deformation induced continuous recrystallisation, initial fibrous grain structures, typical LABs, along the rolling direction gradually shift into equiaxed grains, HABs keep increasing until the transformation of grains is completed (Figure 10), grain orientation is gradually randomized (Figure 11), and texture is weakened. After dynamic recrystallisation is finished, the second stage of superplastic deformation is mainly controlled by grain-boundary sliding.

\section{Existing Challenges and Limitations}

In spite of the inspiring and exciting research outcomes about superplastic formation behavior of $\mathrm{Al}$ alloys, there are still enormous unknown yet critical territories waiting to be found out and developed.

(i) There are still long way to go to develop a synthetical theory to utterly reveal the essence of superplasticity of $\mathrm{Al}$ alloys. 

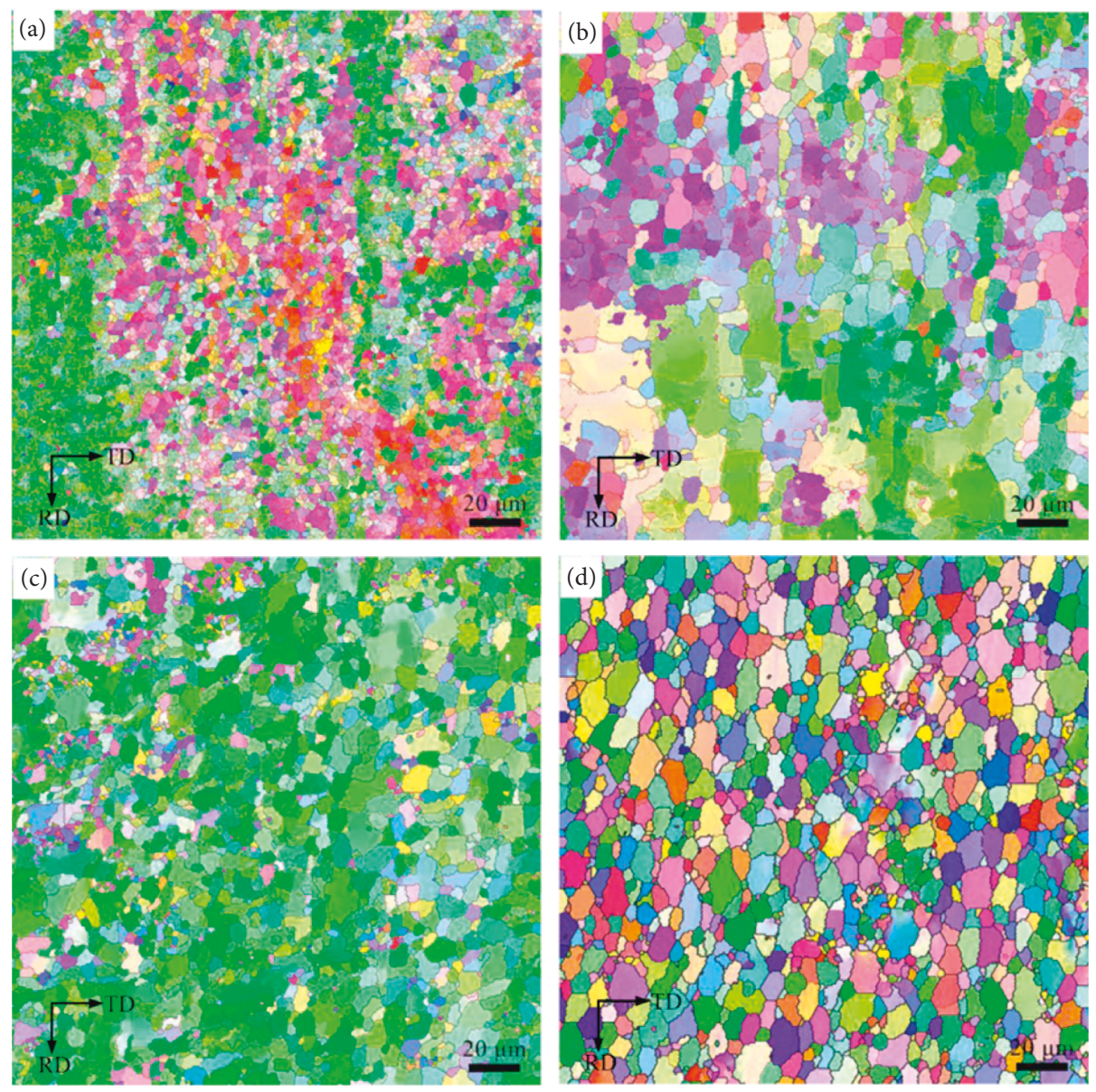

FIgUre 11: EBSD analyses of the Al-Zn-Mg- $0.25 \mathrm{Sc}-0.10 \mathrm{Zr}$ alloy deformed at $500^{\circ} \mathrm{C}$ and $1 \times 10^{-2} \cdot \mathrm{s}^{-1}$ after interrupting the tensile test at different strains: (a) $\varepsilon=0$; (b) $\varepsilon=0.69$; (c) $\varepsilon=1.10$; (d) $\varepsilon=2.40$ [42].

(ii) To exhibit superplasticity, the $\mathrm{Al}$ alloys need to meet the strict microstructure requirements, which are for the alloys to hold equiaxed and fine grains as well as the ability to recrystallisation.

(iii) Superplasticity of $\mathrm{Al}$ alloys also holds specific deformation requests, including high temperatures and low strain rates, which obviously limit the further industrialized and commercial applications of superplastic deformation.

(iv) For now, the applications of advanced severe plastic deformation (SPD) technologies, which are often used to activate superplasticity of $\mathrm{Al}$ alloys, are basically limited to scientific research and study. There is no sign to make SPD technologies fully utilize in commercial process.

(v) There are few researches about combining superplastic deformation with other forming technologies, such as welding and casting, to form complexshaped components.

(vi) It is necessary to keep developing $\mathrm{Al}$ alloys with exceptional and comprehensive properties, including strength, ductility, superplastic formation ability, and stress corrosion resistance, so that the potentials of $\mathrm{Al}$ alloys can be fully released.

\section{Conclusions}

In this paper, the fundamentals and superplastic deformation behaviors of several series of $\mathrm{Al}$ alloys are described and it can be seen that currently the main different kinds of $\mathrm{Al}$ alloys all have exhibited outstanding superplasticity. Furthermore, the mechanisms of superplastic deformation are discussed and various theories regarding superplastic mechanism are summarized and analyzed, including theory of grainboundary sliding with accommodation mechanism and deformation-induced continuous recrystallisation. Meanwhile, factors that affect superplastic deformation process of $\mathrm{Al}$ alloys are explained in detail, including temperatures, stain rates, and thermal-mechanical process. Subsequently, two significant superplastic deformation parameters of different $\mathrm{Al}$ alloys, strain rate sensitivity $(m)$ and deformation activation energy $(Q)$, are compared to help understand the relationship within these two parameters and superplastic deformation mechanisms. Finally, the existing challenges and limitations of current superplastic deformation of $\mathrm{Al}$ alloys are properly summarized.

\section{Conflicts of Interest}

The authors declare that they have no conflicts of interest. 


\section{References}

[1] G. Giuliano, Superplastic Forming of Advanced Metallic Materials: Methods and Applications, Elsevier, 2011.

[2] T. Y. M. Al-Naib and J. L. Duncan, "Superplastic metal forming," International Journal of Mechanical Sciences, vol. 12 , no. 6, pp. 463-470, 1970.

[3] JIS H 7007, Glossary of Terms used in Metallic Superplastic Materials, Japanese Standards Association, Tokyo, Japan, 1995.

[4] V. N. Perevezentsev, V. V. Rybin, and V. N. Chuvil'deev, "The theory of structural superplasticity-III. Boundary migration and grain growth," Acta Metallurgica et Materialia, vol. 40, pp. 907-914, 1992.

[5] A. H. Chokshi, A. K. Mukherjee, and T. G. Langdon, "Superplasticity in advanced materials," Materials Science and Engineering: R: Reports, vol. 10, no. 6, pp. 237-274, 1993.

[6] C. H. Hamilton, "Simulation of static and deformationenhanced grain growth effects on superplastic ductility," Metallurgical Transactions A, vol. 20, no. 12, pp. 2783-2792, 1989.

[7] P. S. Bate, N. Ridley, and B. Zhang, "Mechanical behaviour and microstructural evolution in superplastic $\mathrm{Al}-\mathrm{Li}-\mathrm{Mg}-$ $\mathrm{Cu}-\mathrm{Zr}$ AA8090," Acta Materialia, vol. 55, no. 15, pp. 4995-5006, 2007.

[8] G. Sakai, Z. Horita, and T. G. Langdon, "Grain refinement and superplasticity in an aluminum alloy processed by highpressure torsion," Materials Science and Engineering A, vol. 393, no. 1-2, pp. 344-351, 2005.

[9] C. E. Pearson, "Viscous properties of extruded eutectic alloys of Pb-Sn and Bi-Sn," Journal of Institute Metals, vol. 54, no. 1, pp. 111-123, 1934.

[10] O. Ruano and O. D. Sherby, "On constitutive equations for various diffusion-controlled creep mechanisms," Revue de Physique Appliquee, vol. 23, pp. 625-637, 1988.

[11] B. M. Watts, M. J. Stowell, B. L. Baikie, and D. G. E. Owen, "Superplasticity in Al-Cu-Zr alloys. Part 1: material preparation and properties," Metal Science, vol. 10, pp. 189-197, 1976.

[12] S. Mehta, P. K. Sengupta, K. J. L. Iyer, and K. Nair, "Studies of the superplasticity of high strength aluminium alloy," Aluminium, vol. 68, pp. 234-237, 1992.

[13] J. Xinggang, W. Qingliing, C. Jianzhong, and M. Longxiang, "A study of the improvement," Metallurgical Transactions A, vol. 24, no. 11, pp. 2596-2597, 1993.

[14] J. Xinggang, C. Janzhong, and M. Longxiang, "A study of grain refinement and superplasticity of high strength $7475 \mathrm{Al}$ alloy," Z.Metallkd, vol. 84, pp. 216-219, 1993.

[15] M. Mabuchia and K. Higashib, "On accommodation helper mechanism for superplasticity in metal matrix composites," Acta Materialia, vol. 47, no. 6, pp. 1915-1922, 1999.

[16] H. Huang, G. Fan, and Z. Tan, "Superplastic behavior of carbon nanotube reinforced aluminum composites fabricated by flake powder metallurgy," Materials Science and Engineering: A, vol. 699, pp. 55-61, 2017.

[17] K. Arun Babu, V. Subramanya Sarma, and C. N. Athreya, "Experimental verification of grain boundary-sliding controlled steady state superplastic flow in both continually and statically recrystallizing Al alloys," Materials Science and Engineering: A, vol. 657, pp. 185-196, 2016.

[18] A. Dhal, S. K. Panigrahi, and M. S. Shunmugam, "Insight into the microstructural evolution during cryo-severe plastic deformation and post-deformation annealing of aluminum and its alloys," Journal of Alloys and Compounds, vol. 726, pp. 1205-1219, 2017.

[19] H. P. Pu, F. C. Liu, and J. C. Huang, "Characterization and analysis of low-temperature superplasticity in $8090 \mathrm{Al}-\mathrm{Li}$ alloys," Metallurgical and Materials Transactions A, vol. 26, pp. 1153-1166, 1995.

[20] F. C. Liu and Z. Y. Ma, "Contribution of grain boundary sliding in low-temperature superplasticity of ultrafinegrained aluminum alloys," Scripta Materialia, vol. 62, no. 3, pp. 125-128, 2010.

[21] R. Valiev, "Nanostructuring of metals by severe plastic deformation for advanced properties," Nature Materials, vol. 3, no. 8, pp. 511-516, 2004.

[22] L. B. Johannes, I. Charit, R. S. Mishra, and R. Verma, "Enhanced superplasticity through friction stir processing in continuous cast AA5083 aluminum," Materials Science and Engineering: A, vol. 464, pp. 351-357, 2007.

[23] I. Charit and R. S. Mishra, "Evaluation of microstructure and superplasticity in friction stir processed 5083 Al alloy," Materials Research, vol. 19, no. 11, pp. 3329-3342, 2004.

[24] M. A. García-Bernal, R. S. Mishra, R. Verma, and D. Hernández-Silva, "High strain rate superplasticity in continuous cast $\mathrm{Al}-\mathrm{Mg}$ alloys prepared via friction stir processing," Scripta Materialia, vol. 60, no. 10, pp. 850-853, 2009.

[25] Z. Y. Ma and R. S. Mishra, "Development of ultrafinegrained microstructure and low temperature $(0.48 \mathrm{Tm})$ superplasticity in friction stir processed $\mathrm{Al}-\mathrm{Mg}-\mathrm{Zr}$," Scripta Materialia, vol. 53, no. 1, pp. 75-80, 2005.

[26] A. Orozco-Caballero, M. Álvarez-Leal, P. Hidalgo-Manrique, C. MaríaCepeda-Jiménez, O. Antonio Ruano, and F. Carreño, "Grain size versus microstructural stability in the high strain rate superplastic response of a severely friction stir processed Al-Zn-Mg-Cu alloy," Materials Science and Engineering A, vol. 680, pp. 329-337, 2017.

[27] J. A. del Valle, P. Rey, D. Gesto, D. Verdera, and J. A. Jiménez, "Mechanical properties of ultra-fine grained AZ91 magnesium alloy processed by friction stir processing," Materials Science and Engineering: A, vol. 628, pp. 198-206, 2015.

[28] A. Orozco-Caballero, P. Hidalgo-Manrique, and C. M. Cepeda-Jiménez, "Strategy for severe friction stir processing to obtain acute grain refinement of an $\mathrm{Al}-\mathrm{Zn}-$ $\mathrm{Mg}-\mathrm{Cu}$ alloy in three initial precipitation states," Materials Characterization, vol. 112, pp. 197-205, 2016.

[29] H. Akamatsu, T. Fujinami, Z. Horita, and T. G. Langdon, "Influence of rolling on the superplastic behavior of an AlMg-Sc alloy after ECAP," Scripta Materialia, vol. 44, no. 5, pp. 759-764, 2001.

[30] Z. Horita, M. Furukawa, M. Nemoto, A. J. Barnes, and T. G. Langdon, "Superplastic forming at high strain rates after severe plastic deformation," Acta Materialia, vol. 48, no. 14, pp. 3633-3640, 2000.

[31] K. T. Park, H. J. Lee, C. S. Lee, W. J. Nam, and D. H. Shin, "Enhancement of high strain rate superplastic elongation of a modified $5154 \mathrm{Al}$ by subsequent rolling after equal channel angular pressing," Scripta Materialia, vol. 51, no. 6, pp. 479-483, 2004.

[32] R. Z. Valiev and T. G. Langdon, "Principles of equal-channel angular pressing as a processing tool for grain refinement," Progress in Materials Science, vol. 51, no. 7, pp. 881-981, 2006.

[33] R. B. Figueiredo and T. G. Langdon, "Evaluating the Superplastic Flow of a Magnesium AZ31 Alloy Processed by 
Equal-Channel Angular Pressing," Metallurgical and Materials Transactions A, vol. 45, no. 8, pp. 3197-3204, 2014.

[34] C. M. Cepeda-Jiménez, J. M. García-Infanta, O. A. Ruano, and F. Carreño, "Mechanical properties at room temperature of an $\mathrm{Al}-\mathrm{Zn}-\mathrm{Mg}-\mathrm{Cu}$ alloy processed by equal channel angular pressing," Journal of Alloys and Compounds, vol. 509, pp. 8649-8656, 2011.

[35] C. M. Cepeda-Jiménez and J. M. García-Infanta, "Influence of Processing Severity During Equal-Channel Angular Pressing on the Microstructure of an Al-Zn-Mg-Cu Alloy," Metallurgical and Materials Transactions A, vol. 43, no. 11, pp. 4224-4236, 2012.

[36] L. Jiao, Y. T. Zhao, and W. Yue, "The development of high strain rate and low temperature superplasticity in aluminum matrix composites," Materials Review, vol. 27, pp. 119-123, 2013.

[37] N. Tsuji, K. Shiotsuki, and Y. Saito, "Superplasticity of ultra-fine grained al-mg alloy produced by accumulative roll-bonding," Materials Transactions, JIM, vol. 40, no. 8, pp. 765-771, 1999.

[38] M. Node, M. Hirohashi, and K. Funami, "Low temperature superplasticity and its deformation mechanism in grain refinement of Al-Mg Alloy by multi-axial alternative forging," Materials Transactions, vol. 44, no. 11, pp. 2288-2297, 2003.

[39] Y. T. Zhu, T. C. Lowe, H. Jiang et al., United States Patent Application, USP6197129, 2001.

[40] Y. T. Zhu, H. Jiang, J. Y. Huang et al., "A new route to bulk nanostructured metals," Metallurgical and Materials Transactions A, vol. 32, no. 6, pp. 1559-1562, 2001.

[41] Y. L. Duan, L. Tang, Y. Deng, X. W. Cao, G. F. Xu, and Z. M. Yin, "Superplastic behavior and microstructure evolution of a new Al-Mg-Sc-Zr alloy subjected to a simple thermomechanical processing," Materials Science and Engineering A, vol. 669, pp. 205-217, 2016.

[42] Y. L. Duan, G. F. Xu, X. Y. Peng, Y. Deng, Z. Li, and Z. M. Yin, "Effect of Sc and $\mathrm{Zr}$ additions on grain stability and superplasticity of the simple thermal-mechanical processed Al-Zn-Mg alloy sheet," Materials Science and Engineering A, vol. 648, pp. 80-91, 2015.

[43] M. Li, Q. Pan, Y. Shi, X. Sun, and H. Xiang, "High strain rate superplasticity in an $\mathrm{Al}-\mathrm{Mg}-\mathrm{Sc}-\mathrm{Zr}$ alloy processed via simple rolling," Materials Science and Engineering A, vol. 687, pp. 298-305, 2017.

[44] X. G. Jiang, Q. L. Wu, J. Z. Cui et al., "A new grain-refinement process for superplasticity of high-strength 7075 aluminum alloy," Journal of Materials Science, vol. 28, pp. 6038-6039, 1993.

[45] D. H. Shin, C. S. Lee, and W. Kim, "Superplasticity of finegrained $7475 \mathrm{Al}$ alloy and a proposed new deformation mechanism," Acta Materialia, vol. 45, no. 12, pp. 5195-5202, 1997.

[46] A. Smolej, M. Gnamus, and E. Slacek, "The influence of the thermomechanical processing and forming parameters on superplastic behaviour of the 7475 aluminium alloy," Journal of Materials Processing Technology, vol. 118, no. 1-3, pp. 397-402, 2001.

[47] L. Y. Ye, X. M. Zhang, D. W. Zheng et al., "Superplastic behavior of an Al-Mg-Li alloy," Journal of Alloys and Compounds, vol. 487, no. 1-2, pp. 109-115, 2009.

[48] H. P. Pu and J. C. Huang, "Processing routes for intertransformation between low- and high-temperature 8090 Al-Li superplastic sheets," Scripta Metallurgica et Materialia, vol. 33, no. 3, pp. 383-389.
[49] J. Wadsworth and A. R. Pelton, "Superplastic behavior of a powder-source aluminum-lithium based alloy," Scripta Metallurgica, vol. 18, no. 4, pp. 387-392, 1984.

[50] E. El-Danaf, S. R. Kalidindi, and R. G. Doherty, "Influence of grain size and stacking-fault energy on deformation twinning in fcc metals," Metallurgical and Materials Transactions A, vol. 30, no. 5, pp. 1223-1233, 1999.

[51] A. Rohatgi, K. S. Vecchio, and G. T. Gray III, "A metallographic and quantitative analysis of the influence of stacking fault energy on shock hardening in $\mathrm{Cu}$ and $\mathrm{Cu}-\mathrm{Al}$ alloys," Acta Materialia, vol. 49, pp. 427-438, 2001.

[52] N. Zhang, Y. Wang, and H. Hou, "Superplastic deformation behavior of 7B04 Al alloy," Journal of Materials Engineering, vol. 45, pp. 27-33, 2017.

[53] A. V. Mikhaylovsaya, O. A. Yakovtseva, and M. N. Sitkina, "Comparison between superplastic deformation mechanisms at primary and steady stages of the fine grain AA7475 aluminium alloy," Materials Science and Engineering A, vol. 718, pp. 277-286, 2018.

[54] M. Kh Rabinovich and V. G. Trifonof, "Dynamic grain growth during superplastic deformation," Acta Materialia, vol. 44, no. 5, pp. 2073-2078, 1996.

[55] P. Zhang, L. Ye, X. Zhang, G. Gu, H. Jiang, and Y. Wu, "Grain structure and microtexture evolution during superplastic deformation of 5A90 Al-Li alloy," Transactions of Nonferrous Metals Society of China, vol. 24, no. 7, pp. 2088-2093, 2014.

[56] Y. Duan, G. Xu, L. Zhou, and D. Xiao, "Achieving high superplasticity of a traditional thermal-mechanical processed non-superplastic $\mathrm{Al}-\mathrm{Zn}-\mathrm{Mg}$ alloy sheet by low Sc additions," Journal of alloys and compounds, vol. 638, pp. 364-373, 2015.

[57] H. Xiang, Q. L. Pan, X. H. Yu, X. Huang, X. Sun, and $\mathrm{X}$. D. Wang, "Superplasticity behaviors of Al-Zn-Mg-Zr cold-rolled alloy sheet with minor Sc addition," Materials Science Engineering A, vol. 676, pp. 128-137, 2016.

[58] L. Ye, X. Zhang, and D. Zheng, "Superplastic behavior of an Al-Mg-Li alloy," Journal of alloys and compounds, vol. 487, pp. 109-115, 2009.

[59] L. Jiao, Research on Plastic Deformation Behavior and Properties of In Situ Particulate Reinforced Aluminum Matrix Composites, Jiangsu University, Suzhou, China, 2014.

[60] O. Roder, T. Gysler, and G. Lütjering, "Fatigue properties of Al-Mg alloys with and without scandium," Materials Science and Engineering A, vol. 234-236, pp. 181-184, 1997.

[61] R. J. Dashwood, R. Grimes, A. W. Harrison, and H. M. Flower, "The Development of a High Strain Rate Superplastic Al-Mg-Zr Alloy," Materials Science Forum, vol. 357-359, pp. 339-344, 2001.

[62] R. Grimes, R. J. Dashwood, A. W. Harrison, and H. M. Flower, "Development of a high strain rate superplastic Al-Mg-Zr alloy," Materials Science and Technology, vol. 16, no. 11-12, pp. 1334-1339, 2000.

[63] D. H. Bae and A. K. Ghosh, "Grain size and temperature dependence of superplastic deformation in an $\mathrm{Al}-\mathrm{Mg}$ alloy under isostructural condition," Acta Materialia, vol. 48, no. 6, pp. 1207-1224, 2000.

[64] A. Smolej, D. Klobčar, B. Skaza et al., "Superplasticity of the rolled and friction stir processed $\mathrm{Al}-4.5 \mathrm{Mg}-0.35 \mathrm{Sc}-0.15 \mathrm{Zr}$ alloy," Materials Science and Engineering A, vol. 590, pp. 239-245, 2014.

[65] M. Furukawa, P Berbon, and T. G. Langdon, "Age hardening and the potential for superplasticity in a fine-grained $\mathrm{Al}-\mathrm{Mg}$ - 
Li-Zr alloy," Metallurgical and Materials Transactions A, vol. 29, no. 1, pp. 169-177, 1998.

[66] M. Furukawa, Y. Iwahashi, Z. Horita, and M. Nemoto, "Structural evolution and the Hall-Petch relationship in an Al-Mg-Li-Zr alloy with ultra-fine grain size," Acta Materialia, vol. 45, no. 11, pp. 4751-4757, 1997.

[67] L. Man-ping, S. Shao-chun, H. J. Roven et al., "Deformation defects and electron irradiation effect in nanostructured $\mathrm{Al}-\mathrm{Mg}$ alloy processed by severe plastic deformation," Transactions of Nonferrous Metals Society of China, vol. 22, no. 8, pp. 1810-1816, 2012.

[68] A. V. Mikhaylovskaya, O. A. Yakovtseva, I. S. Glolovin, and A. V. Pozdniakov, "Superplastic deformation mechanisms in fine-grained Al-Mg based alloys," Materials Science and Engineering A, vol. 627, pp. 31-41, 2015.

[69] G. Xu, X. Cao, T. Zhang, Y. Duan, X. Peng, and Y. Deng, "Achieving high strain rate superplasticity of an Al-MgSc-Zr alloy by a new asymmetrical rolling technology," Materials Science and Engineering A, vol. 672, pp. 98-107, 2016.

[70] R. J. Rioja and J. Liu, "The Evolution of Al-Li base products for aerospace and space applications," Metallurgical and Materials Transactions A, vol. 43, no. 9, pp. 3325-3337, 2012.

[71] H. Yin, H. Li, X. Su, and D. Huang, "Processing maps and microstructural evolution of isothermal compressed $\mathrm{Al}-\mathrm{Cu}-\mathrm{Li}$ alloy," Materials Science and Engineering A, vol. 586, pp. 115-122, 2013.

[72] Y. Lin and Z. Zheng, "Microstructural evolution of $2099 \mathrm{Al} \mathrm{Li}$ alloy during friction stir welding process," Materials Characterization, vol. 123, pp. 307-314, 2017.

[73] Y. Lin, Z. Zheng, S. Li, X. Kong, and Y. Han, "Microstructures and properties of 2099 Al-Li alloy," Materials Characterization, vol. 84, pp. 88-99, 2013.

[74] A. A. Mazilkin and M. M. Myshlyaev, "Microstructure and thermal stabilityof superplastic aluminium-lithium alloy after severe plastic deformation," Journal of Materials Science, vol. 41, no. 12, pp. 3767-3772, 2006.

[75] R. Kaibyshev, K. Shipilova, and F. Musin, "Achieving high strain rate superplasticity in an $\mathrm{Al}-\mathrm{Li}-\mathrm{Mg}$ alloy through equal channel angular extrusion," Materials Science and Technology, vol. 21, no. 4, pp. 408-418, 2005.

[76] X. Zhang, L. Xie, L. Ye, and Panzhang, "Effect of aging treatment on grain refinement and superplasticity of 2A97 aluminum-lithium alloy," Heat Treatment of Metals, vol. 39, pp. 88-92, 2014.

[77] M. Taheri-Mandarjani, A. Zarei-Hanzaki, and H. R. Abedi, "Hot ductility behavior of an extruded 7075 aluminum alloy," Materials Science and Engineering A, vol. 637, pp. 107-122, 2015.

[78] K. Ma, T. Hu, H. Yang, T. Topping, A. Yousefiani, and E. J. Lavernia, "Coupling of dislocations and precipitates: Impact on the mechanical behavior of ultrafine grained Al-Zn-Mg alloys," Acta Materialia, vol. 103, pp. 153-164, 2016.

[79] P. K. Rout, M. M. Ghosh, and K. S. Ghosh, "Microstructural, mechanical and electrochemical behaviour of a $7017 \mathrm{Al}-$ $\mathrm{Zn}-\mathrm{Mg}$ alloy of different tempers," Materials Characterization, vol. 104, pp. 49-60, 2015.

[80] K. Sotoudeh and P. S. Bate, "Diffusion creep and superplasticity in aluminium alloys," Acta Materialia, vol. 58, no. 6, pp. 1909-1920, 2010.

[81] J. Liu and D. J. Chakrabarti, "Grain structure and microtexture evolution during superplastic forming of a high strength Al-Zn-Mg-Cu alloy," Acta Materialia, vol. 44, no. 12 , pp. $4647-4661,1996$.

[82] X. Cao, G. Xu, Y. Duan, Z. Yin, and L. Lu, "Achieving high superplasticity of a new $\mathrm{Al}-\mathrm{Mg}-\mathrm{Sc}-\mathrm{Zr}$ alloy sheet prepared by a simple thermal-mechanical process," Materials Science and Engineering A, vol. 647, pp. 333-343, 2015.

[83] X. Xu, J. Zheng, Z. Li, R. Luo, and B. Chen, "Precipitation in an $\mathrm{Al}-\mathrm{Zn}-\mathrm{Mg}-\mathrm{Cu}$ alloy during isothermal aging: Atomicscale HAADF-STEM investigation," Materials Science and Engineering A, vol. 691, pp. 60-70, 2017.

[84] K. Wen, Y. Fan, G. Wang, L. Jin, X. Li, and Z. Li, "Aging behavior and fatigue crack propagation of high $\mathrm{Zn}$-containing Al-Zn-Mg-Cu alloys with zinc variation," Materials Science and Engineering A, vol. 27, pp. 217-227, 2017.

[85] F. Jiang, H. S. Zurob, G. R. Purdy, and H. Zhang, "Characterizing precipitate evolution of an $\mathrm{Al}-\mathrm{Zn}-\mathrm{Mg}$-Cu-based commercial alloy during artificial aging and non-isothermal heat treatments by in situ electrical resistivity monitoring," Materials Science and Engineering: A, vol. 117, pp. 47-56, 2016.

[86] K. Wang, F. C. Liu, Z. Y. Ma, and F. C. Zhang, "Realization of exceptionally high elongation at high strain rate in a friction stir processed $\mathrm{Al}-\mathrm{Zn}-\mathrm{Mg}-\mathrm{Cu}$ alloy with the presence of liquid phase," Scripta Materialia, vol. 64, no. 6, pp. 572-575, 2011.

[87] A. V. Mikhaylovskaya, O. A. Yakovtseva, V. V. Cheverikin, and A. D. kotov, "Superplastic behaviour of Al-Mg-Zn-ZrSc-based alloys at high strain rates," Materials Science and Engineering A, vol. 659, pp. 225-233, 2016.

[88] R. Kaibyshev, E. Avtokratova, A. Apollonov, and R. Davies, "High strain rate superplasticity in an $\mathrm{Al}-\mathrm{Mg}-\mathrm{Sc}-\mathrm{Zr}$ alloy subjected to simple thermomechanical processing," Scripta Materialia, vol. 54, no. 12, pp. 2119-2124, 2006.

[89] I. Charit and R. S. Mishra, "Low temperature superplasticity in a friction-stir-processed ultrafine grained $\mathrm{Al}-\mathrm{Zn}-\mathrm{Mg}-\mathrm{Sc}$ alloy," Acta Materialia, vol. 53, no. 15, pp. 4211-4223, 2005.

[90] R. Raj, "A mechanistic basis for high strain rate superplasticity of aluminum based metal matrix composites," Materials Science and Engineering, vol. 215, no. 1-2, pp. 1-8, 1996.

[91] V. N. Perevezentsev and K. Higashi, "Theoretical Investigation of High Strain Rate Superplasticity," Materials Science Forum, vol. 304-306, pp. 217-224, 1999.

[92] M. Mabuchi, K. Higashi, K. Inoue et al., "Experimental investigation of superplastic behavior in a $20 \mathrm{vol} \%$ aluminum composite," Scripta Metallurgica et Materialia, vol. 26, no. 12, pp. 1839-1844, 1992.

[93] K. Higashi, T. Okada, T. Mukai et al., "Superplastic behavior in a mechanically alloyed aluminum composite reinforced with SiC particulates," Scripta Metallurgica et Materialia, vol. 26, no. 2, pp. 185-190, 1992.

[94] M. Mabuchi, K. Higashi, and T. G. Langdon, "An investigation of the role of a liquid phase in $\mathrm{Al}-\mathrm{Cu}-\mathrm{Mg}$ metal matrix composites exhibiting high strain rate superplasticity," Acta Metallurgica et Materialia, vol. 42, no. 5, pp. 1739-1745, 1994.

[95] C. Tang, M. Li, Z. Li et al., "Superplasticity of Al composite fabricated by spray deposition processing," Journal of Materials Engineering, vol. 3, pp. 17-19, 1996.

[96] G. H. Zahid, R. I. Todd, and P. B. Prangnell, "Superplasticity in an alulllinium alloy 2124/SiCp composite," Materials Science and Technology, vol. 14, no. 9, pp. 901-905, 1998.

[97] X. Xu, W. Wang, and L. Cai, "Superplasticity of A SiCP/6A02 Al composite," Materials for Mechanical Engineering, vol. 26, no. 9, pp. 20-21, 2002. 
[98] X. Xu, K. Chen, F. Dai, and L. Cai, "Investigation on superplasticity of $\mathrm{SiC}$ particulate reinforced aluminum matrix composite," Acta Metallurgica Sinica, vol. 38, no. 5, pp. 544-548, 2000.

[99] F. R. Cao, H. Ding, Y. L. Li, G. Zhou, and J. Z. Cui, "Superplasticity, dynamic grain growth and deformation mechanism in ultra-light two-phase magnesium-lithium alloys," Materials Science and Engineering A, vol. 527, no. 9, 2010.

[100] I. I. Novikov, V. K. Portnoy, V. S. Levchenko, and A. O. Nikiforov, "Subscolidus superplasticity of aluminium alloys," Materials Science Forum, vol. 243-245, pp. 463-468, 1997.

[101] J. C. Tan and M. J. Tan, "Superplasticity and grain boundary sliding characteristics in two stage deformation of $\mathrm{Mg}-$ $3 \mathrm{Al}-1 \mathrm{Zn}$ alloy sheet," Materials Science and Engineering A, vol. 339, no. 1-2, pp. 81-89, 2003.

[102] O. A. Ruano and O. D. Sherby, "On constitutive equations for various diffusion-controlled creep mechanisms," Revue de Physique Appliquee, vol. 23, no. 4, pp. 625-637, 1988.

[103] T. G. Nieh, J. Wadsworth, and O. D. Sherby, Superplasticity in Metals and Ceramics, Cambridge University Press, Cambridge, UK, 1997.

[104] M. E. Kassner and M. T. Pérez-Prado, "Five-power-law creep in single phase metals and alloys," Progress in Materials Science, vol. 45, no. 1, pp. 1-102, 2000.

[105] Y. L. Duan, G. F. Xu, D. Xiao, L. Q. Zhou, Y. Deng, and Z. M. Yin, "Excellent superplasticity and deformation mechanism of $\mathrm{Al}-\mathrm{Mg}-\mathrm{Sc}-\mathrm{Zr}$ alloy processed via simple free forging," Materials Science and Engineering A, vol. 624, pp. 124-131, 2015.

[106] J. Liu and D. J. Chakrabarti, "Grain structure and microtexture evolution during superplastic forming of a high strength $\mathrm{Al}-\mathrm{Zn}-\mathrm{Mg}-\mathrm{Cu}$ alloy," Acta Materialia, vol. 44, no. 12, pp. 4641-4661, 1996.

[107] X. Cao, G. Xu, Y. Duan, Z. Yin, and Y. Wang, "Achieving high superplasticity of a new $\mathrm{Al}-\mathrm{Mg}-\mathrm{Sc}-\mathrm{Zr}$ alloy sheet prepared by a simple thermal-mechanical process," Materials Science and Engineering A, vol. 647, pp. 333-343, 2015.

[108] P. S. Bate, F. J. Humpherys, N. Ridley, and B. Zhang, "Microstructure and texture evolution in the tension of superplastic Al-6Cu-0.4Zr," Acta Materialia, vol. 53, no. 10, pp. 3059-3069, 2005.

[109] S. Katsas, R. Dashwood, R. Grimes, M. Jackson, G. Todd, and $\mathrm{H}$. Henein, "Dynamic recrystallisation and superplasticity in pure aluminium with zirconium addition," Materials Science and Engineering A, vol. 444, no. 1-2, pp. 291-297, 2007.

[110] K. Sotoudeh and P. S. Bate, "Diffusion creep and superplasticity in aluminium alloys," Acta Materialia, vol. 58, no. 6, pp. 1909-1920, 2010.

[111] R. H. Bricknell and J. W. Ddington, "Superplasticity in the commercial Al-Zn-Mg alloy BA 708," Metallurgical Transactions $A$, vol. 7, no. 1, pp. 153-154, 1976.

[112] J. A. del Valle, M. Teresa Pérez-Prado, and O. A. Ruano, "Symbiosis between grain boundary sliding and slip creep to obtain high-strain-rate superplasticity in aluminum alloys," Journal of the European Ceramic Society, vol. 27, no. 11, pp. 3385-3390, 2007.

[113] L. B. Johannes and R. S. Mishra, "Multiple passes of friction stir processing for the creation of superplastic 7075 aluminum," Materials Science and Engineering A, vol. 464, no. 1-2, pp. 255-260, 2007.
[114] A. Ball, "Superplasticity in the aluminium-zinc eutectoid-an early model revisited," Materials Science and Engineering A, vol. 234-236, pp. 365-369, 1997.

[115] A. K. Mukherjee, "The rate controlling mechanism in superplasticity," Materials Science and Engineering, vol. 8, no. 2, pp. 83-89, 1971.

[116] R. G. Gifkins, "Grain-boundary sliding and its accommodation during creep and superplasticity," Metallurgical Transactions A, vol. 7, no. 8, pp. 1225-1232, 1976.

[117] A. Ball and M. M. Hutchison, "Superplasticity in the Aluminium-Zinc Eutectoid," Journal of Metal Science, vol. 3, pp. 1-7, 1969.

[118] K. Mukherjee, "The rate controlling mechanism in superplasticity," Materials Science and Engineering, vol. 8, no. 2, pp. 83-89, 1971.

[119] M. F. Ashby and R. A. Verrall, "Diffusion-accommodated flow and superplasticity," Acta Metallurgica, vol. 21, no. 2, pp. 149-163, 1973.

[120] W. A. Backofen, I. R. Turner, and D. H. Avery, "Superplasticity in an Al-Zn alloy," Transactions of ASM, vol. 57, pp. 980-990, 1964.

[121] K. I. Sugimoto, U. Noboru, M. Kobayashi et al., "Effects of volume fraction and stability of retained austenite on ductility of TRIP-aided dual-phase steels," ISIJ International, vol. 32, no. 12, pp. 1311-1318, 1992.

[122] A. Orozco-Caballero and A. Orozco-Caballero, "Grain size versus microstructural stability in the high strain rate superplastic response of a severely friction stir processed Al-Zn-Mg-Cu alloy," Materials Science and Engineering A, vol. 680, pp. 329-337, 2017.

[123] N. Fakhar, F. Fereshteh-Saniee, and R. Mahmudi, "High strain-rate superplasticity of fine- and ultrafine-grained AA5083 aluminum alloy at intermediate temperatures," Materials and Design, vol. 85, pp. 342-348, 2015.

[124] N. Fakhar, F. Fereshteh-Saniee, and R. Mahmudi, "Grain refinement and high strain rate superplasticity in alumunium 2024 alloy processed by high-pressure torsion," Materials Science and Engineering A, vol. 622, pp. 139-145, 2015.

[125] J. Lei, W. Xiaolu, and L. Hui, "High strain rate superplasticity of in situ $\mathrm{Al} 3 \mathrm{Zr} / 6063 \mathrm{Al}$ composites," Rare Metal Materials and Engineering, vol. 45, no. 11, pp. 2798-2803, 2016.

[126] B. Kim, J. C. Kim, S. Lee, and K.-S. Lee, "High-strain-rate superplasticity of fine-grained $\mathrm{Mg}-6 \mathrm{Zn}-0.5 \mathrm{Zr}$ alloy subjected to low-temperature indirect extrusion," Scripta Materialia, vol. 141, pp. 138-142, 2017.

[127] A. Orozco-Caballero, C. M. Cepeda-Jiménez, and P. Hidalgo-Manrique, "Lowering the temperature for high strain rate superplasticity in an $\mathrm{Al}-\mathrm{Mg}-\mathrm{Zn}-\mathrm{Cu}$ alloy via cooled friction stir processing," Materials Chemistry and Physics, vol. 142, no. 1, pp. 182-185, 2013.

[128] Z. Y. Ma, R. S. Mishra, M. W. Mahoney, and R. Grimes, "High strain rate superplasticity in friction stir processed $\mathrm{Al}-\mathrm{Mg}-\mathrm{Zr}$ alloy," Materials Science and Engineering A, vol. 351, no. 1-2, pp. 148-153, 2003.

[129] Z. Y. Ma and R. S. Mishra, "Development of ultrafinegrained microstructure and low temperature $(0.48 \mathrm{Tm})$ superplasticity in friction stir processed Al-Mg-Zr," Scripta Materialia, vol. 53, pp. 75-80, 2005.

[130] T. G. Nieh, L. M. Hsiung, J. Wadsworth, and R. Kaibyshev, "High strain rate superplasticity in a continuously recrystallized Al-6\%Mg-0.3\%Sc alloy," Acta Materialia, vol. 46, no. 8, pp. 2789-2880, 1998. 
[131] K. L. Kending and D. B. Miracle, "Strengthening mechanisms of an Al-Mg-Sc-Zr alloy," Acta Materialia, vol. 50, no. 16, pp. 4165-4175, 2002.

[132] Y. N. Wang and J. C. Huang, "Comparison of grain boundary sliding in fine grained $\mathrm{Mg}$ and $\mathrm{Al}$ alloys during superplastic deformation," Scripta Materialia, vol. 48, no. 8, pp. 11171122, 2003.

[133] K. T. Park, S. H. Myung, D. H. Shin, and C. S. Lee, "Size and distribution of particles and voids pre-existing in equal channel angular pressed $5083 \mathrm{Al}$ alloy: their effect on cavitation during low-temperature superplastic deformation," Materials Science and Engineering, vol. 371, no. 1-2, pp. 178-186, 2004. 


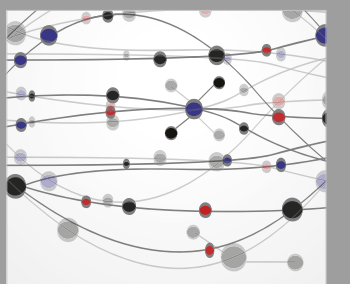

The Scientific World Journal
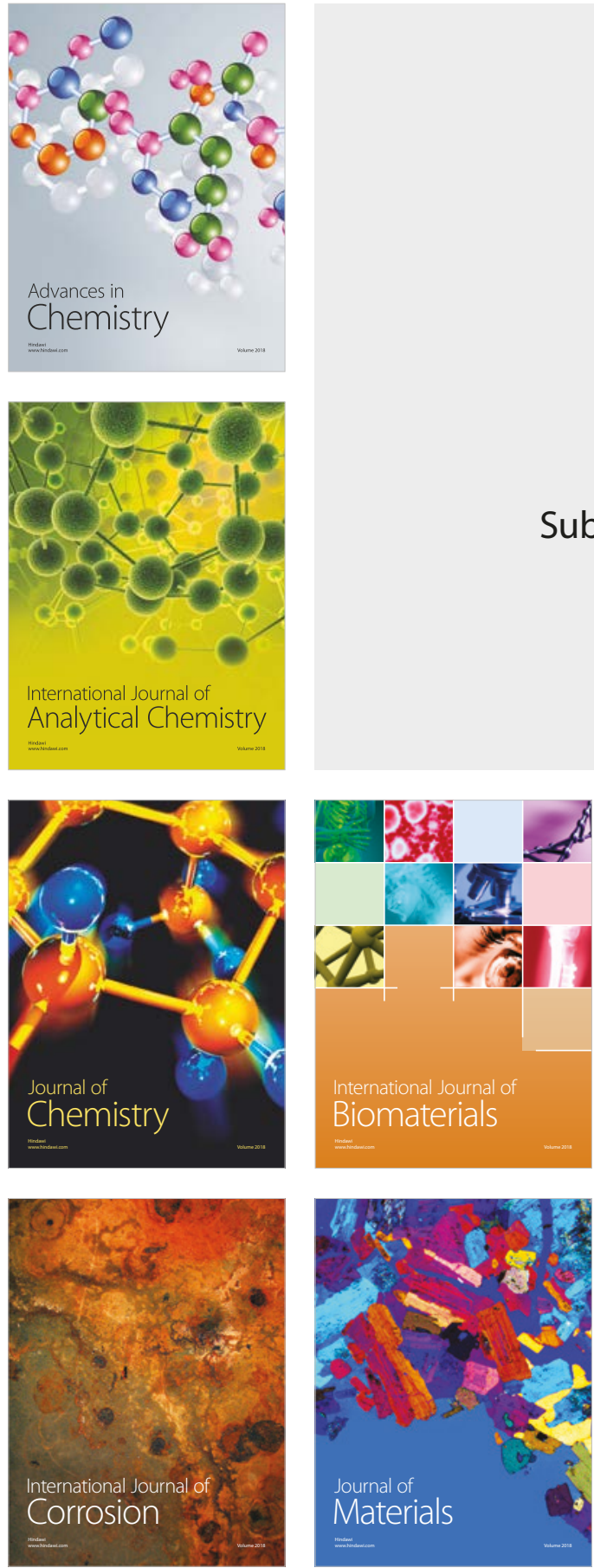

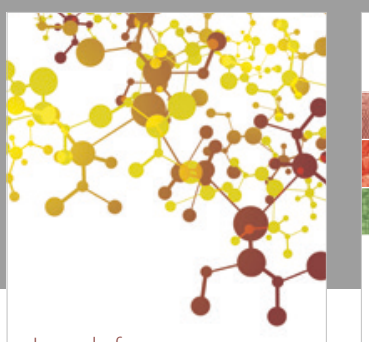

Journal of

Applied Chemistry
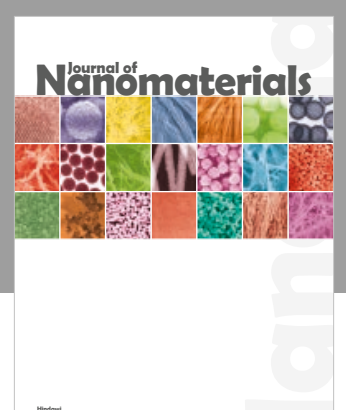

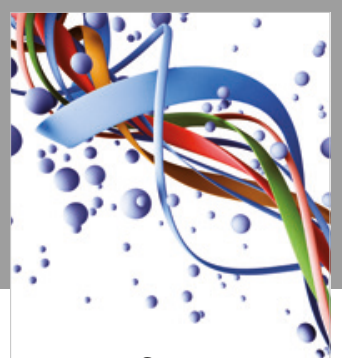

Scientifica

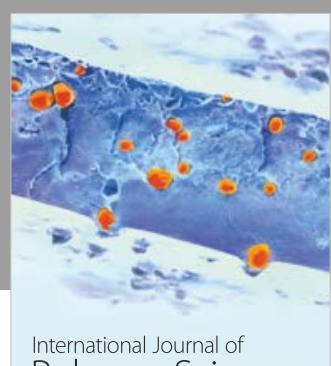

Polymer Science

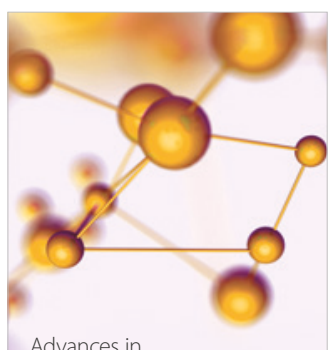

Physical Chemistry
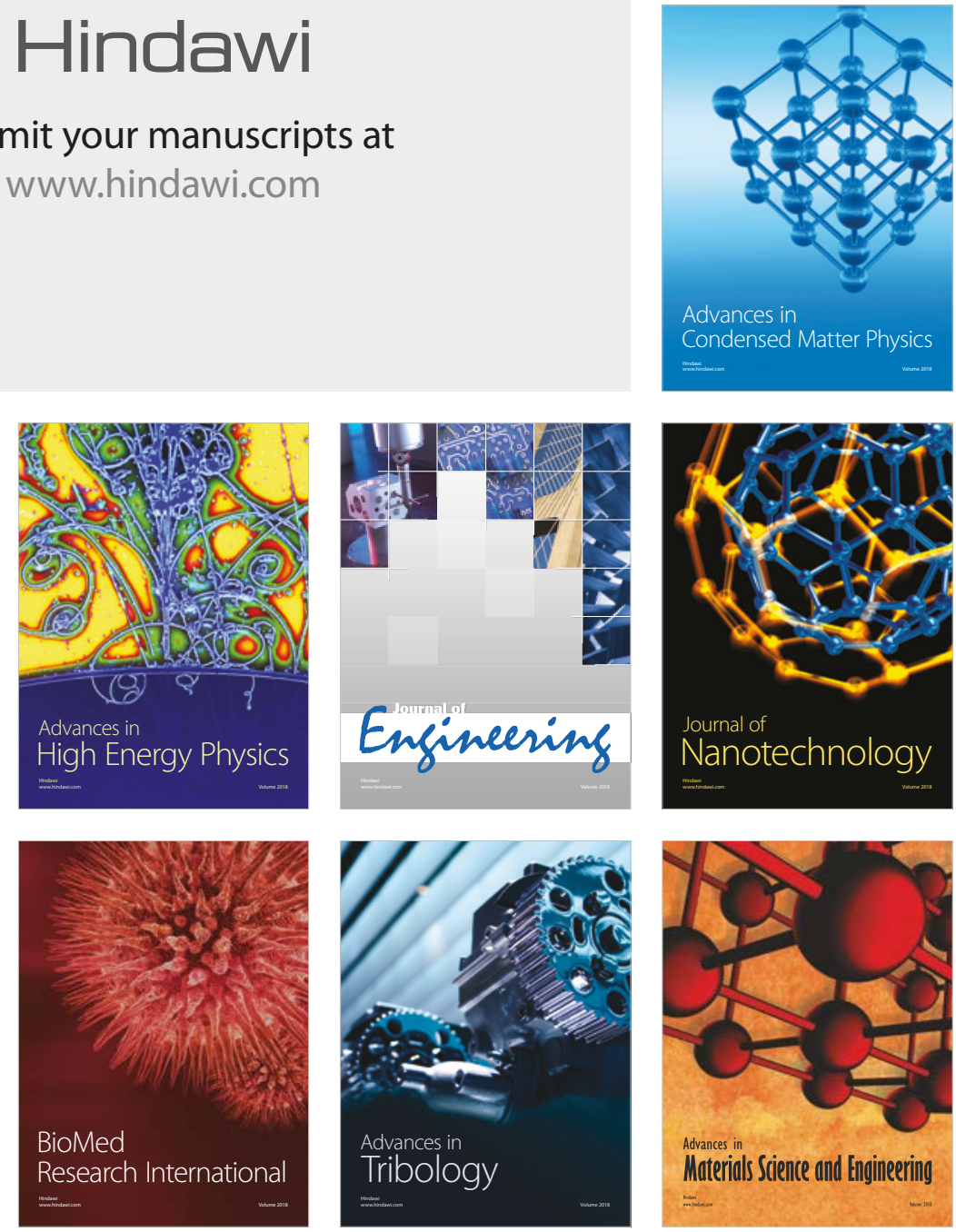